\title{
REVIEWS
}

\section{Wall Street Versus Main Street: How Ignorance, Hyperbole, and Fear Lead to Regulation}

\author{
Jonathan R. Macey†
}

F.I.A.S.C.O.: Blood in the Water on Wall Street. Frank Partnoy. Norton, 1997. Pp 13, 252.

For two years in the early 1990s, Frank Partnoy worked for a couple of investment banks (CS First Boston and Morgan Stanley) selling derivatives. He made a lot of money domg this. Now he is trying to make a hittle more money from his experience by writing a sensationalist book about his time at Morgan Stanley. The book is clearly patterned after Michael Lewis's bestseller, Liar's Poker, which chrouncled the author's life as a bond salesman for Salomon Brothers in the 1980s. ${ }^{1}$

What F.I.A.S.C.O. ${ }^{2}$ and Liar's Poker have in common, and the reason they are of intorest to those studying the regulation of the financial markets, is the way the two books depict the relationship between investment banks and their clients. These books provide significant ammunition to those intorested in regulating

$\dagger$ J. DuPratt White Professor of Law and Director of the John M. Olin Program in Law and Economics, Cornell Law School.

' Michael M. Lewis, Liar's Poker: Rising Through the Wreckage on Wall Street (Norton 1989).

2 "F.I.A.S.C.O." stands for "Fixed Income Annual Sporting Clays Outing," an acronym used by those at Morgan Stanley to describe an annual outing to a private shooting range (p 14). 
the securities markets by characterizing the investment banks as willing and able to take advantage of their chents' naïvete. Similarly, they are of intorest to those of us concerned with norms, particularly the reputational norms that operate in business environments.

In its depiction of the norms at work in the investment banks, the perspective presented in F.I.A.S.C.O. is fundamentally at odds with economic theory. Morgan Stanley is portrayed in F.I.A.S.C.O. as interested only in short-term profits at the expense of long-torm relationships. Partnoy details a world where customers are routinely and systematically swindled and tricked into buying inappropriate, high-risk derivative securities that provide ultra-high commissions to the Morgan Stanley traders. In one vignette, for example, Partnoy even suggests that the investment bank's conduct was scarcely different than that of an organized criminal operation:

Overall, Morgan Stanley's actions were barely distinguishable from those of a drug kingpin seeking an appropriate tax haven to launder money. Morgan Stanley was taking precisely the same stops drug dealers took to evade U.S. regulators. The only real difference between the actions of a drug kingpin and those of Morgan Stanley was that $\$ 12,000$ of drug money rarely found its way te a charity for Bermuda schoolgirls ( $p$ 83).

Clearly, Partnoy's incomplete understanding of how markets work skewed his perception of the environment in which he found himself during his brief stint on Wall Street.

This Review begins with an analysis of the derivative transaction that hes at the core of Partnoy's book and that sets the stage for everything that follows. I argue that F.I.A.S.C.O. fundamentally mischaracterizes the transaction it purports to describe. Next, I provide an alternative account of a securities transaction that I beheve more accurately portrays both the economic reality and the underlying social agenda of a modern investment banking firm like Morgan Stanley. In the final Section of this Review, I pay further attention to Partnoy's claim that derivatives should be regulated more extensively than they are now. 


\section{FRANK PARTNOY'S VISION OF THE WORLD}

A. Ripping Off Faces: The Story of the PERLS Transaction

\section{Partnoy's account.}

Partnoy's spin on the events he is describing in F.I.A.S.C.O. is most clear from his description of the sale by Morgan Stanley of a derivative security called PERLS ("Principal Exchange Rate Linked Security"). A look at Partnoy's version of events, followed by a skeptical analysis, exemplifies the faulty reasoning at work in F.I.A.S.C.O.

PERLS are fixed-income investments in which the issuer calculates the amount of principal owed at maturity by taking the nominal or stated principal amount and multiplying it by a formula linked to foreign currencies ( $p$ 55). Thus, PERLS permit investors and issuers to hedge and speculate on foreign currency movements. Partnoy explains one type of PERLS security this way:

[O]ne popular PERLS, instead of repaying the principal amount of $\$ 100$, paid the $\$ 100$ principal amount multiplied by the change in the value of the U.S. dollar, plus twice the change in the value of the Britisl pound, minus twice the change in the value of the Swiss franc. The principal repayment was linked to these three different currencies, hence the name Principal Exchange Rate Linked Security (p 56).

Partnoy forcefully asserts that his colleagues at Morgan Stanley sold PERLS to unsuspecting customers who thought they were buying simple AAA-rated bonds. These buyers, according to Partnoy, had absolutely no idea what they were doing, or what risks they were assuming. Such customers "looked at a terin sheet for PERLS, and all they saw was a bond. The complex formulas eluded them; their eyes glazed over. The fact that the bonds' principal payinents were linked te changes in foreigu currency ratos was simply incomprehensible" (p 57). Furthernnore, Partnoy insinuates that Morgan Stanley customers were not only too unsophisticatod te realize the risks they were assuming, but that Morgan Stanley salesmen systematically duped them into making highly leveraged bets on foreign exchange rates. The motivation for this deception was the fact that salesmen earned a higher commission on the sale of PERLS than on the sale of ordinary bonds ( $p$ 57). 
To support his allegations, Partnoy recounts a story that he claims to have heard shortly after joining the derivatives product group at Morgan Stanley. A derivative salesman told Partnoy about a conversation he had with a "senior treasury officer" from an insurance company that had recently bought $\$ 85$ million in face amount of PERLS. The officer called the Morgan Stanley salesman who had consummatod the trade to find out the current value of the investment. The salesman broke the news that, in a matter of weeks, the PERLS had plummetod to a fraction of their original value. When the insurance company official expressed shock and incredulity, the salesman went on to explain that, in purchasing the PERLS, the officer had assumed a foreign exchange risk that went sour (pp 60-61).

According to Partnoy, "[t]his salesman had earned a giant commission on this PERLS trade, and he laughed uncontrollably at his story. When [the salesman] finished his story, he asked me if I knew what it was called when a salesman did what he had done to one of his chents. I [Frank Partnoy] said I didn't know. He told me it was called 'ripping his face off'" ( $p$ 61). Partnoy goes on as follows:

"Ripping his face off?" I asked, wondering if I had heard him correctly. "Yes," he replied. He then explained, in graphic, warlike detail how you grabbed the chent under the neck, pinched a fold of skin, and yanked hard, tearing as much flesh as you could. I never will forget how this salesman looked me in the eye and, with a serious sense of pride, almost a toar, summed up this particular PERLS trade. "Frank," he said, "I ripped his face off" ( $p$ 61).

\section{The real story.}

This account of the experience of an anguished Morgan Stanley derivatives customer captures the essence of F.I.A.S.C.O. Partnoy is clearly under the impression that the investment hanks and their salesmen, motivated by greed, purposely mislead investors. The question is whether his story is credible.

At least three things suggest that the salesman's account should not be taken at face value. First, contrary to Partnoy's repeatod assertions to the contrary, no special sophistication is required to understand this kind of trade. Indeed, by the author's own account, the salesman who arranged this trade was able to explain the transaction in seven words: "You made a big foreign exchange bet" ( $p$ 60). Unless the salesman fraudulently charactorized the PERLS security prior to sale or the investment offi- 
cers of this insurance company were truly incompetent, it is difficult to understand how the custemer could fail to understand the nature of this transaction. Put another way, while the exact methodology used to value this derivative instrument is highly complex, the basic dynamics of the pricing is simple. It can basically be described like this: when foreign currencies weaken against the U.S. dollar, this particular PERLS loses value; when these currencies strengthen against the dollar, the PERLS gains value. Surely the customer could have understood this simple explanation.

Second, it is hard to credit the customer's fundamental misunderstanding about the basics of this trade in hight of the fact that the PERLS sold in this transaction were priced to give the customer a rate of interest well above the market rate for a simple bond. Even more telling, the very name of this security, PERLS, clearly indicates that the principal payment is linked to foreign exchange rates. After all, these instruments are called "Principal Exchange Rate Linked Securities" and not "bonds." Again, absent outright fraud (for example, a salesman making up a false acronym for these securities) or incompetence on the part of the insurance company officials, it is impossible to imagine how a customer could be duped about the fundamental nature of this transaction in the way Partnoy describes.

A third indication that the events being recounted (thirdhand) probably did not happen in precisely the way that Partnoy asserts is that the salesman telling this story is claiming that he was "ripping his customer's face off" at the same time that he was issuing detailed and specific warnings to his customer about the risks the customer was taking. When the customer complained to the salesman, the salesman purportedly reminded him that, prior te the sale, the salesman had explained the foreign exchange risks inherent in the transaction, and the fact that these risks accounted for the above-market rate of interest on the security: "When you buy PERLS, you take foreign exchange risk. That's why you were getting an above-market coupon on the bond. I told you that. ... Come on, why did you think you'd be getting such a high coupon if you weren't taking any risk?" ( $p$ 61). The Morgan Stanley salesman's account of what actually took place is fundamentally at odds with the suggestion that the salesman set out purposely to take advantage of the insurance company by selling a very risky, highly leveraged derivative instrument that the client thought was a plain-vanilla bond. More accurately understood, the insurance company officer has taken an interest bet and lost. It hardly seems surprising that ex post, after the loss, 
the customer has a strong incentive to complain that he didn't understand the nature of the transaction. The customer's declaration of ignorance is not only not surprising, it is also not credible. As the Morgan Stanley salesman pointed out, the risks of the trade were suggested by the security's price (in the form of the interest rate), and no reasonably sophisticated customer could have been unaware of that.

Partnoy's characterization of the salesman's motives is most likely as inaccurate as his depiction of the transaction. Partnoy claims that Morgan Stanley salesinen pushed risky derivatives on unsuspecting custemers in order to earn the higher commissions associated with selling derivatives. However, if customers were this easy to rip off, it would make more sense for an unscrupulous salesman simply te sell a security suited to the customer's investment needs, but at an artificially inflated price. This would allow the salesman to earn a higher commission while preserving a valuable business relationship.

The plausibility of Partnoy's characterization is further weakened by noting that he describes the allegedly victimized chent as a "stodgy insurance company" ( $p$ 60). By "stedgy," the author wants us to beheve that derivative securities were unsuitable to the buyer's needs. But the more important piece of information is that the buyer is an insurance company. This fact is relevant because the insurance industry is highly regulated. Insurance companies' investments are restricted, and, in particular, insurance companies often are not permitted to speculate in foreign currency transactions. PERLS were often used by insurance companies as a device that provided the risk-return characteristics of foreign exchange trading but had the appearance, from a regulatory perspective, of a generic fixed-income investment. In other words, PERLS were used by unscrupulous insurance company portfoho managers as a means of creating loopholes, either in existing insurance company (or pension fund) regulations or in company pohicy. ${ }^{3}$ Similarly, professional investers often are limited te making investments with certain ratings from credit agencies, or with companies whose payoffs are denominated in certain currencies. Derivatives can permit these investors to make riskier investments while staying within the confines of these restrictions.

${ }^{3}$ Partnoy himself appears to recognize this fact. He points out that "PERLS were especially attractive to devious managers at insurance companies, many of whom wanted to place foreign currency bets without the knowledge of the regulators or their bosses. PERLS were designed to allow such cheater managers to gamble in the volatile foreign exchange futures and options markets" (p 57). 
Accordingly, it appears far more plausible that the unscrupulous party in the trade Partnoy is describing was not the Morgan Stanley salesman, but rather the insurance company purchaser. After all, it was the purchaser who tried to renege on the deal by playing dumb when foreign exchange rates went the wrong way. And, more fundamentally, it was the purchaser who, in all likelihood, was using PERLS in order to evade some regulation or intrafirm rule restricting precisely the sort of gamble contained in these investments.

Furthermore, there is nothing in Partnoy's account to suggest that these customers were unknowing dupes. It was purchasers who initially wanted complex derivative instruments in order to avoid restrictions on the sorts of investments they might make. The supply of derivatives created by First Boston, Morgan Stanley, and other firms came partially in response to this demand. There was nothing illegal about the trades, and the customers knowingly accepted the huge risks associated with derivatives. Partnoy claims that all PERLS buyers fell into one of two basic categories: "widows and orphans" and "cheaters" (p 56). He spends a lot of time talking about the widows and orphans, but precious little time talking about the clieaters. Interestingly, however, he doesn't describe any actual transactions with widows and orphans, only witl cleaters. Indeed, despito Partnoy's claims to the contrary ( $\mathrm{p}$ 60), the "stodgy insurance company" left so bereft after the PERLS transaction was not a widow or an orplian. On the contrary, the insurance company was most likely a cheater.

\section{B. The AMIT Episode: Another Distortion}

In addition to hedging and speculating-and avoiding investment restrictions in the case of insurance and pension funds-derivative instruments are created to clean up the balance sheets of certain corporato chents. Sometimes these balance sheet operations are ethical, and sometimes they are not. Partnoy, however, once again mischaracterizes a useful, and demanded, financial tool as highly unethical.

Among the myriad of benign uses for derivatives, a manufacturing firm miglit employ a simgle-swap transaction to exchange a floating-rato payment obligation for a fixed-rate payment obhigation, or to exchange an obligation to make payments in German marks for an obhgation to make the payments in U.S. dollars. ${ }^{4}$

4 For simple, but more detailed accounts of both a foreign currency swap and an interest rate swap, see Jonatban R. Macey, Derivative Instruments: Lessons for the Regula- 
These sorts of transactions are desirable to firms because such exchanges can make the firms' balance sheets more transparent, rendering them easier for investors and regulators to evaluato. For example, a firm that swaps payment obhgations in marks for payment obhgations in dollars might be more readily valued if the firm's balance sheet is denominatod in dollars. (However, foreign exchange risk has not been eliminated; the risk has merely shifted from risk about the value of a mark to risk about the value of a dollar.)

However, derivatives may also be used for less benign ends. Firms in countries with lax accounting standards or comphant regulators can use derivatives to mask holes in their balance sheet. Perhaps the best example of how derivatives might be used for purposes of accounting or regulatory obfuscation involves the Japanese banks. According to F.I.A.S.C.O., Japanese banks liked to use U.S. investment banks with branches in Tokyo rather than Japanese investment firms when structuring fraudulent transactions because Japan's Ministry of Finance had no regulatory authority over U.S. investment banks ( $p$ 214). Partnoy's characterization would come as a surprise to these American banks, who beheve themselves to be regulated by the Ministry of Finance. The appeal of U.S. investment banks to Japanese investers is more accurately explained by the wealth of American expertise. As Partnoy acknowledges, U.S. banks were the only firms with the sophistication and creativity te structure the complex transactions that the Japanese clients wanted ( $p$ 214). This was the real reason many Japanese firms gave their business to U.S. investment banks.

The derivative instrument Morgan Stanley created for the Japanese was called an AMIT ("American Mortgage Investment Trust"). An AMIT is comprised of two components: a particular type of CMO ("Collateralized Mortgage Obhgation") called an IOette and a zero coupon bond. The first part of the AMIT, the customized CMO, is created from mortgage-backed securities, which are bonds where the cash used to make principal and interest payments comes from bundling together pools of home mortgage obhgations. To create a CMO, the issuer combines the principal and intorest payment obligations on a mortgage-backed security and divides it into sub-parts, called strips. Usually the strips are either interest-only strips (IOs) or principal-only strips (POs), but other, nore exotic combinations exist. An IOette is a strip that is comprised of a particular combination of IOs and 
POs. In an IOette, the IO portion of the security is many times the size of the PO portion ( $p$ 222). Because the interest portion of an IOette vastly dominates the smaller principal portion, the market price of these securities is a large multiple (called a premium) of the face amount of the bond components.

Morgan Stanley created IOettes by buying large amounts of mortgage-backed securities and carving out most of the principal payment obligations. Morgan Stanley then kept the majority of the principal payment obligations in its inventery, and sold the interest payment obligations as the first component of the AMIT. The custemer who purchased the IOette was then obligated under the terms of the trade te give Morgan Stanley an option with respect te the inventoried principal payment obhigations. Specifically, the client had to agree to make up for any losses that Morgan Stanley might suffer from market fluctuations that caused the principal-only portion of the IOette to lose value. Besides the IOette, the second part of an AMIT is comprised of a smiple zero coupon bond. These are bonds that do not make periodic interest payments. The investor's return comes from the difference between the price he initially pays for the security and the price he receives from the issuer at maturity. Zero coupon bonds are the opposite of IOettes in that they trade at a large discount from the face amount of these bonds.

As created by Morgan Stanley for its Japanese clients, an AMIT is a combination of IOettes and zero coupon bonds in equal face amounts. While the face amounts of the two parts of the AMIT were the same, the market value of the components, if traded separately, would be much different because of the different intrinsic characteristics of IOettes and zero coupon bonds. In particular, the IOettes would be worth a lot more than the zero coupon bond. In addition to receiving the face amount of the IOette as a return on their investment, huyers would also receive a series of future payments, namely the interest portion of the IOette. By contrast, from the zero coupon bond, investors would receive only the principal payment, which would not be realized for quite some time. Despite the fact that the two pieces of these AMIT's were worth vastly different amounts, the Japanese investors would pay the same price for each half of the AMIT. This, of course, meant that the investors were paying too little for the IOette portion, and too much for the zero coupon bond portion.

According to Partnoy's account of Morgan Stanley's AMIT trades, immediately after purchasing the AMITs, the Japanese investor would resell to Morgan Stanley the one-half of the face amount of the AMITs that was comprised of the IOettes. By re- 
purchasing the IOette at the market price shortly after selling the securities at a drastically discounted price, Morgan Stanley permitted the Japanese investers to book a huge paper profit. Of course, the Japanese bank should show a huge loss from the zero coupon bond component of the AMITs, because it had overpaid for them. However, apparently the firms to which Morgan Stanley was selling these derivatives did not have to account for the market value of these instruments on their books, so they would not have to show the loss for many years ( $p$ 215). Furthermore, although Morgan Stanley teok a loss in repurchasing the IOettes at inarket price after recently selling them at a discount, the investment bank did not mind, because it was more than able to make up for the losses on repurchase through a combination of its profits from the sale of the zero coupon bond portion of the AMITs and the huge fee it collected for structuring the transaction. To bring things full circle, after Morgan Stanley repurchased the IOettes, it would recombine the interest and principal coinponents of the IOette with the remaining principal component that it had stripped out and inventoried when originally creating the IOette. Morgan Stanley would then sell these reconstituted mortgage-backed securities back te Fannie Mae, the government agency from whom it had bought them in the first place.

As evidence of Partnoy's condemnation of the AMIT episode, F.I.A.S.C.O. contains an account of a particularly large pair of AMIT trades ( $\$ 471.48$ million) that took only two weeks te put together and thanks to which Morgan Stanley inade an astronomical profit of $\$ 75$ million (pp 217-33). As Partnoy explains, the hon's share of the $\$ 75$ million profit came from the fact that there were large increases in the bond market during the period after the Japanese investor had purchased the AMITs but before Morgan Stanley repurchased, repackaged, and resold the IOettes to Fannie Mae. This bond market made the principal-only portion that Morgan Stanley placed into its inventory when it created the IOette extreinely valuable.

Partnoy suggests that there was something unethical about the large profit that Morgan Stanley earned on this particnlar AMIT trade (which, for some reason, was called the "MX trade"). He asserts that the firm "arguably would be violating the chent's trust" by keeping such a huge profit ( $p$ 231). Curiously, Partnoy inakes this suggestion despite the fact that the agreement "clearly allowed Morgan Stanley te keep all the profits" from the MX trade ( $p$ 231). His argument is unconvincing. The Japanese client (whom Partnoy assumes to be a large institutional invester) could easily value the principal-only portion of the invest- 
ment by looking at bond prices. Moreover, Morgan Stanley's profits came from general movements in interest rates during the period of time that the transaction was outstanding: Morgan Stanley did not manipulate the market or exploit an informational advantage in order to realize this profit.

The more interesting aspect of these AMIT transactions is that they were designed specifically to exploit accounting loopholes in order to permit the chents purchasing these derivatives immediately to book huge gains for accounting purposes, while postponing for years the need to show the concomitant losses. As Partnoy observes, "the AMIT proved to be the most efficient means anyone has been able to devise for generating false income for Japanese investors" ( $p$ 233). Partnoy fails to recognize the fact that the Japanese investor probably did not want te call attention to this quasi-clandestine trade by falsely claiming a share in the profits Morgan Stanley realized on the principal-only portion of the transaction. The point of the AMIT transactions is that these derivatives were not designed and sold as a means of defrauding customers. Rather, at worst, they were designed and sold in order to permit sophisticated Japanese customers to hide corporate losses from regulators by showing huge profits in other areas. And, frankly, I am skeptical that the regulaters were really fooled. In hight of the pattern of complicity between Japanese regulators and Japanese financial institutions, it seems more likely that both regulators and firms were working together to mask these losses, because such losses would make them both look bad.

\section{PLUS Notes: Yet Another Distortion}

Japan was not the only venue in which Morgan Stanley may have helped sophisticated customers use financial alchemy to accomplish accounting gimmickry. In 1994, Morgan Stanley created a new derivative, called PLUS notes ("Peso-Linked U.S. Dollar Secured Note"), to permit certain Mexican banks (particularly Banco Nacional de Mexico) to remove what Partnoy describes as "undervalued and illiquid" inflation-linked bonds from their balance sheets without having to record any losses for accounting purposes. Banco Nacional was unwilling to simply sell the bonds, which are known as Bonos Ajustables del Gobierno Federal (adjustable bonds of the Mexican government), because a straight forward sale would have forced the bank to record an accounting loss. The story of the derivative transactions executed by Morgan Stanley on behalf of Banco Nacional provides the setting for one of F.I.A.S.C.O.'s more misleading moral lessons. 
Investment banks trying to help Banco Nacional and other Mexican banks sell Mexican sovereign debt to institutional investors in the Unitod States and Europe faced the problem that these investors wanted highly rated (that is, investment grade) securities, and they wanted them denominated in U.S. dollars rather than in Mexican pesos. These twin preferences were problematic because only Mexican debt denominated in pesos was investment grade. This was due to the fact that rating agencies are very comfortable in assuring investors that the Mexican government will pay back its obhgations that are denominated in pesos, because the government can always simply print more pesos to cover its debt. But if the peso falls in value against the dollar, the Mexican government umght not be able to meet its obhgations to repay in dollars. It might, for example, suspend the convertibility of its currency, as it had done in the past. Thus, the Bonos Ajustables that Banco Nacional wished to sell were given a high, investment grade AA- rating by Standard \& Poor's, but they were payable in Mexican pesos rather than in U.S. dollars.

In order to rid Banco Nacional of its Bonos Ajustables, Morgan Stanley created a Bermuda corporation, which in turn created and sold its own bonds backed by the Mexican securities. These were the bonds known as PLUS notes. Unlike the Bonos Ajustables, the PLUS notes were denominated in U.S. dollars. Morgan Stanley convinced Standard \& Poor's to give the new bonds issued by the Bermuda company the same AA- rating given te Mexico's peso-denominatod sovereign debt, instead of the inuch lower rating given to Mexico's U.S. dollar-denominated debt.

Although Partnoy suggests that the PLUS notes did not deserve an investment grade rating, the Standard \& Poor's rating was sound for two good reasons. First, the bonds were not issued on a one-for-one basis. In other words, each $\$ 1$ in bonds sold were backed by more than $\$ 1$ of Bonos Ajustables. This gave buyers a cushion against interest rate fluctuations. To provide an even further layer of protection, the Bermuda company bought U.S. treasury bonds in order to use their interest and principal to repay purchasers. Second, Morgan Stanley caused the issuing company te enter into a swap transaction in which it would commit to convert the payments made in pesos by Mexico on the Bonos Ajustables inte U.S. dollars, thereby protecting against the currency risk that had troubled investors.

The PLUS notes enabled Banco Nacional to do what it wanted-rid itself of the Bonos Ajustables without recognizing a sale for accounting purposes. Banco Nacional did this by assuming ownership of the Bermuda company that bought the peso- 
denominated Bonos Ajustables and issued the dollar-denominated derivative bonds. This ownership allowed Banco Nacional to include the assets of the Bermuda company as its own assets. Because the assets of the Bermuda company included the Bonos Ajustables, Banco Nacional had not sold these securities and therefore did not need to show an accounting loss (pp 80-85).

Partnoy tries to create the impression that every aspect of the PLUS notes sale contains some element of sleaze. First, he suggests that the pubhic did not want the bonds being sold, claiming that the seller "was looking to do the impossible: sell bonds into a market that didn't want the bonds, without having to admit publicly that it was selling them" (p 80). This is false; the public did want the bonds that were sold. What buyers didn't want were peso-denominatod bonds, and the public was not asked to buy those. Further, Partnoy incorrectly suggests that the PLUS transaction involved "convincing someone to buy" the pesodenominated Bonos Ajustables (p 81). In fact, the deal was structured in order to satisfy the interests of buyers: they were purchasing dollar-denominated bonds with significant credit enlianceinents.

Second, Partnoy struggles te convey the image that this transaction bordered on illegal fraud, and could only have been consummated with the help of a corrupt government in Bermuda. He claims that the small franchise fees and taxes $(\$ 1,600$ per year) paid by Morgan Stanley and Banco Nacional clooked like kickbacks" ( $p$ 83). This statement borders on the farcical. It is no more corrupt for Bermuda to charge franchise fees and taxes to foreign firms wishing to incorporate there than it is for Delaware to charge such fees. Moreover, there is not the shghtest suggestion that Bermudan officials benefited personally from these transactions. Partnoy even manages to suggest that something nefarious lay behind the requirement in Bermuda law that a qualified charitable institution be the owner of the new company's stock (pp 82-83). There is nothing corrupt, however, about creating regulations that benefit local clrarities. That is what 26 USC \&501(c)(3) status does for not-for-profit institutions in the United Statos. Additionally, the combination of educational and cliaritable entities involved in this particular transaction (the Bermuda Higln School for Girls and the Lady Cubitt Compassionato Association, among others) hardly seems objectionable (p 83).

Partnoy even suggests that the rating agency Standard \& Poor's was corrupt in giving the PLUS notes an investment grade ratimg. He insinuates that the fact that "private entities can pay for their credit rating" (p 83) means that the rating agencies sell 
their ratings for cash, and he imphes that the general impression that "credit rating agencies are principled and accurate" is misguided ( $p$ 83). Worst of all, Partnoy creates the false impression that Standard \& Poor's did not agree to give the new bonds a high rating until it was paid a "huge fee" (p 85). Rating agencies, however, do not charge higher fees for better ratings. Indeed, the only reason that rating agencies are able to charge fees at all is because the pubhic has enough confidence in the integrity of these ratings to find them of value in evaluating the riskiness of investinents.

Partnoy's account of the rating of the PLUS notes reveals the basic analytical flaw that hes at the heart of F.I.A.S.C.O. The author does not understand the important role reputation plays on Wall Street. The following Section provides an alternative depiction of the dynamics of the derivatives industry that contrasts sharply with the one created by Partnoy. It is an alternative that I find far more plausible.

\section{AN ALTERNATIVE REALITY}

The goal of F.I.A.S.C.O. is to create the impression that the derivatives market in general and the Morgan Stanley derivatives group in particular is in business to dupe unsophisticated, unsuspecting customers. According to Partnoy, the only norm at work among those who sell derivative securities is the desire to create a false sense of security in order to induce customers to buy, and to "lure people into that calm and then just totally fuck 'em" ( $p$ 66). Not only does the entire industry make "huge amounts of money . .. by trickery and deceit" ( $p$ 30), but the way "you made money selling derivatives was by trying to blow up your chents" ( $p$ 65). As Partnoy tells it, derivatives trades are simply the most recent example of a basic theme in the histery of finance: "Wall Street bilks Main Street" ( $p$ 251). The reality is that the stery of derivatives contained in this book is, at worst, "Wall Street and Main Street bilk regulators." Main Street comes out pretty well.

For example, despito the dozens of examples of derivatives trades in F.I.A.S.C.O., Partnoy does not provide a single firsthand account of Morgan Stanley or any other investment bank taking advantage of an unsuspecting customer. Indeed, the book includes only one description of a derivatives transaction with an individual investor. This trade was an equity swap between Bankers Trust and A. Lorne Weil, chairman of Autotote Corporation (p 184). Bankers Trust paid Weil $\$ 13.4$ million for 500,000 of Weil's Autotote shares plus floating interest on the $\$ 13.4$ million. 
Weil, in exchange, agreed to pay Bankers Trust all of the dividends on the shares, and to make additional payments after five years if the stock price increased. (Weil would receive additional payments if the stock prices decreased.) The swap effectively allowed Weil to sell his Autotote stock without having to pay capital gains taxes on the sale, and without having to give up his voting power in the company. As Partnoy points out, these socalled "Equity Swaps" "were a pure, unadulterated tax scam" (p 184). In other words, this trade comports with the trades described in the previous Section. They were motivated by regulatory and accounting concerns. They were not the result of an effort by Wall Street investment banks to defraud their customers.

Similarly, there is unquestionably ample evidence that the derivatives buyers that Partnoy describes were taking huge bets. However, there is no evidence that they were making unreasonable bets in the sense that they were taking gambles for which there was a significant downside without any corresponding upside. Moreover, far from being kept in the dark, there was plenty of voluntary disclosure in the derivatives trading that Partnoy describes (pp 61, 63-65). ${ }^{5}$

Although Partnoy does not give any concrete examples of derivatives salesmen cheating their customers, the circumstances Partnoy describes may nonetheless create at least an opportunity for such deception. What Partnoy fails to recognize, however, is that the investment banks for which these salesmen work have strong incentives to avoid such conduct. In economic jargon, the transactions that Partnoy describes might be explained as the result of a combination of agency problems and time-inconsistency problems within Wall Street firms. The agency problems refer to the fact that investment banking employees such as traders and salesmen are agents of the principals who own the firm. As agents, sometimes their private interests diverge from the interests of the firms' owners. The time-inconsistoncy problem results from the fact that the losses associated with derivatives trades sometimes will not be recognized for some period of time. For example, in the PERLS transaction described above, Partnoy claims that "selling a ... PERLS to a widow or orphan buyer meant that you didn't have to worry about the repayment of principal for five years-an entire career on Wall Street" ( $p$ 60). And, of course, the

- Perhaps not surprisingly, Partnoy characterizes such disclosures as evidence of the investment banks' willingness te take advantage of their customers. He transforms a series of routine disclaimers on an offering memorandum prepared by CS First Boston for some Thai baht basket-hinked notes it was selling into a "remarkable" attempt by First Boston at "covering their asses" (p 64). 
whole point of the IOettes trades described in the previous Section was to permit buyers to book huge profits immediatoly, while postponing the accompanying losses.

The time-inconsistoncy issue combined with the agency cost problem could potontially creato an opportunity for an unscrupulous salesman. Such a salesman could try to gain a short-term advantage by selling unsuitable derivative securities to an unsuspecting customer, provided that the true nature of the trade would not be revealed until after the salesman had left the firm. But the critical point, which Partnoy does not appear to understand, is that the investment banking firms whose salesmen were peddling these securities generally stood to lose far more than the customers. An investment bank that systomatically tried to cheat its customers would lose its reputation, and, because capital is fungible, reputation is the ouly thing that enables investment banks to distinguish themselves from their competitors. Thus, although the huge commissions to be made on individual trades may give Wall Street salesmen an incentive to cheat their customers, the firms that these salesmen work for have strong incentives to pohice against this kind of conduct. ${ }^{6}$

Even Partnoy recognizes that investment banks depend a great deal on their reputations. He devotes considerable space at the outset of F.I.A.S.C.O. to rhapsodizing about the exalted reputation of his former firm, Morgan Stanley. Also, the characterization of Morgan Stanley as "among the most prestigious investment banks" is a recurring theme throughout the book (p 251). Furthermore, Partnoy acknowledges that when considering mergers with other investment banks, Morgan Stanley was careful not to do anything that "jeopardize[d] its hallowed name" (p 176).

From an economic perspective, Morgan Stanley simply has too much invested in its reputation to risk it all on short-term profits from unscrupulous derivative trades. It is more plausible that individual traders may have attempted to free-ride on the firm's reputation by engineering unscrupulous derivatives trades. For the salesmen to be successful, however, not only must these individual traders have short-term time horizons, but the firm itself must have extremely weak monitoring systems in place. This

- Other writers about derivatives have similarly failed to distinguish between the incentives of salesmen and the incentives of the firms for which they work. See Henry T.C. Hu, Misunderstood Derivatives: The Causes of Informational Failure and the Promise of Regulatory Incrementalism, 102 Yale L J 1457, 1492-93 (1993) (arguing that derivatives are one of the few areas on Wall Street where it is still possible for traders to cheat, because of the large amounts of money involved). 
latter claim is highly implausible in light of the fact that the complex financial engineering in derivatives creates massive amounts of leverage, which pose huge risks to the investment banks. Any firm involved in derivatives must have credible intornal monitoring and governance systems in place if it is to have long-term hopes for survival. This is the lesson of the failure of the venerable British investment bank, Barings PLC. As I have pointod out before with regard to the Barings collapse,

shockingly bad internal control systems permitted a single rogue trader to engage in a pattern of highly speculative trading, which resulted in losses to Barings of approximatoly $\$ 1$ billion. ... The Barings insolvency demonstrates that derivative securities trading presents garden variety problems of corporate governance and oversight: nothing more and nothing less. Barings got what it deserved for its lax monitoring practices. ${ }^{7}$

Partnoy's highly conjectural depictions of Morgan Stanley's business practices stand in sharp contrast to actual industry behavior. In investment banking more than in most businesses, relationships with custemers matter more than short-term gains. This is not a result of abstract moral considerations. Businessmen are ethical because it is in their rational self-interest to act ethically. For example, in late 1996, CS First Boston Europe gave up $\$ 80$ million in legally earned trading profits in order to protect the firm's relationship with the Republic of Italy. ${ }^{8}$ The trade involved securities called buoni postali fruittiferi a termine (nicknamed "golden bonds") issued by the Italian postal service but backed by the full faith and credit of the Italian government.

These securities were unusual in a number of ways. In particular, the rate of intorest they offered investors could only be altered by an act of the Italian parhament. Unfortunately for Italian taxpayers, when Italian interest rates started to fall as a result of the convergence of interest rates among European countries preceding the European monetary union; the interest rates on the buoni postali fruittiferi a termine remained high. At one point, the return on the buoni postali fruittiferi a termine was 9.58 percent when comparable government bonds were offering returns of only 7.80 percent. $^{9}$

For clever bond traders, the spread between the rate of returns on the buoni postali fruittiferi a termine and the rate of re-

- Macey, $21 \mathrm{~J}$ Corp L at 79-80 (cited in note 4).

- See Steven Irvine, Italy, The temptation of St David, Euromoney 35, 35 (Jan 1997).

$\rightarrow$ Id. 
turn on other government debt offered a hugely tempting arbitrage possibility. To exploit this possibility, CS First Boston traders not only purchased a large number of bonds for investment purposes, they also planned to act as lead manager for a public issue of the lira equivalent of $\$ 400$ million of the bonds. CS First Boston planned to consummate a large currency swap transaction that would allow it to offer repayment in dollars instead of lire for the notos. Euromoney magazine estimatos CS First Boston's profits from its buoni postali fruittiferi a termine transactions at $\$ 80$ million. ${ }^{10}$ These profits were earned over a very brief period of several days, were entirely riskless, and were legal.

But the trade was deeply embarrassing to the Italian government. CS First Boston decided that the firm's long-torm relationship with the Italian government-and its reputation as an ethical actor-was worth more to it than even an extraordinarily large profit on a simgle transaction. So CS First Boston decided to forego its profits on the transaction by unwinding the swap transactions and accompanying hedges that constituted the profitable public issue the firm had concoctod to take advantage of the buoni postali fruittiferi a termine arbitrage opportunity. This transaction transformed a huge profit for CS First Boston into a modest loss. As David Mulford, Chairman of CS First Boston Europe, explained:

If you're a major global firm that is, "a relationship bank," then in most cases like this where there are conflicts of intorest, the overall relationship will prevail ....

The implications are mucl broader than just Italy. We have important advisory roles around the world. We cannot afford to send out the message, "Well, you're a valuable client for our advisory business, but Im sorry, if we can do a profitable one-off trade that may be against your intorest, we'll do it." This is not a theme we should put in the market. ${ }^{11}$

Like CS First Boston, Morgan Stanley has huge incentives to monitor its salesmen to make sure that the value of the firm's reputation, which has taken decades to create, is not destroyed by a group of rogue derivatives traders. Accordingly, the firm must make sure that the derivatives sold by Morgan Stanley are used for their intonded functions. Partnoy's implications notwithstanding, derivative securities do, in most circumstances, serve legitimate investment functions. Specifically, derivative instru-

"Id at 39. 
ments are securities designed primarily to assist firms in their own risk management. Derivatives serve a number of other worthwhile functions as well. For example, they can be used to help firms reduce the transaction and agency costs of doing business. A firm that wants to extend credit to another firm but is worried that the borrowing firm will change its behavior in the future in ways that creato more risk for the lender can design option-like derivative instruments that force the borrower to buy the securities under certain conditions. Similarly, interest rate reset notes cause interest rates to adjust when there are changes in a borrower's credit rating after a loan has been made, ${ }^{12}$ reducing borrowers' incentives to increase risks ex post. And, as noted above, custemers also want derivatives in order to avoid taxes and other regulations, and to maximize revenues by making leveraged bets on interest rate and currency fluctuations. Only Partnoy's rather grasping and wholly irresponsible sensationalism could transform these very ordinary business objectives into a vast international Wall Street conspiracy.

For firms interested in surviving beyond the short term, ethics is good busmess. Those firms that develop a reputation for ethical practices will find it easier to keep old customers and to attract new customers in an increasingly competitive industry. One passage from F.I.A.S.C.O. in particular reveals this point. Partnoy recounts the stery of one of his immediate supervisors (whom Partnoy strangely refuses to identify except by the code name "Scarecrow") who changed positions within Morgan Stanley, moving from the derivatives products group to the asset management group. Partnoy recounts that:

It had been difficult for him to get the job, and he had been forced te compete against numerous candidates outside the firm. The key question in his interviews had been, What are the most important qualities a salesman can have? The interviewer told Scarecrow the firm had recently conducted a survey about such qualities and asked him to pick his favorito among: product knowledge, intelligence, relationship ability and integrity. Scarecrow said he had answered, "Without a doubt, integrity. This is a trust business, and we are selling our trust." That answer had clinched the job (p 250).

${ }^{12}$ See John D. Finnerty, An Overview of Corporate Securities Innovation, $4 \mathrm{~J}$ App Corp Fin 23, 26-27 (Winter 1992). 


\section{REGULATORY ISSUES}

F.I.A.S.C.O. portrays the business of creating and selling complex derivative instruments as one in which norms of good behavior are completely lacking. And of course, when norms or incentives do not push human behavior in socially acceptable directions, cries for regulation become more plausible. Unsurprisingly, Partnoy's solution for the lawlessness he sees in the derivative industry is regulation. He blames the lack of regulation of the derivatives industry on a combination of "healthy campaign contributions" and the fact that high powered lobbyists "have persuaded our elected representatives to reduce the amount of derivatives regulation, [by] arguing that derivatives are used primarily for 'hedging' and 'risk reduction purposes"' (p 252). Partnoy bemoans the fact that "regulators lack both power and money, and are doomed to remain several stops behind the finance industry" ( $p$ 252).

Partnoy's argument about the lack of regulation in the derivatives industry is unconvincing for three reasons. First, it fails to account for the fact that the securities industry in general is heavily regulated. It makes no sense to argue, as Partnoy does, that firms like Morgan Stanley have the political clout to avoid regulation of their derivatives business but not to avoid regulation of the rest of their business. This argument applies with particular force to commercial banking firms like Bankers Trust that lhave been heavily involved in derivatives, yet are shackled in other areas of their business by outmoded regulations like the Glass-Steagall Act.

Second, and even more fundamentally, Partnoy fails to understand the basic regulatory point that regulation would improve rather than harm the competitive position of industry giants like Morgan Stanley. The fixed costs associated with regulation inevitably would impose barriers to entry on new competitors, thereby permitting firms like Morgan Stanley to sohdify their existing market positions. Long ago George Stigler recognized that regulation, including regulation of the securities markets, provided significant benefits to competitors by cartelizing the industry. ${ }^{13}$ Partnoy's naive claim that industry participants like Morgan Stanley would be liarmed by regulation shows a remarkable lack of understanding of the economic theory of regulation. ${ }^{14}$ In particular, because investors are a diffuse and poorly

\footnotetext{
${ }^{13}$ See George Stigler, Public Regulation of the Securities Markets, 37 J Bus 117 (1964).

14 For an account of the economic theory of regulation (often referred to as public choice) as applied to the Securities and Exchange Commission, see Jonathan R. Macey,
} 
organized interest group, it seems particularly likely that regulations would benefit market participants rather than the public.

Finally, Partnoy's ill-informed musings about the lack of regulation of the derivatives markets do not account for the fact that disinterested federal judges who have considered the issue have refused to interfere with derivatives markets, despite clear authority to do so. The failure to regulate thus comes not only from pohtically inalleable legislators but also from federal judges who are immune to what Partnoy describes as inulti-million dollar securities industry payments "to lobbyists and congressional campaigns to fend off regulation" ( $p$ 252).

Judicial authority to intervene in the derivatives market comes from the securities laws, which provide broad protection for both sophisticated and unsophisticated investors against fraudulent conduct by securities firms. ${ }^{15}$ In particular, courts have interpretod Section 10(b) of the Securities Exchange Act of 1934 and SEC Rule 10b-5 as prohibiting securities brokers from recommending or purchasing securities with an intent to defraud or with reckless disregard for the customer's interests. ${ }^{16}$ Courts also use these laws te prohibit brokers from fraudulently misrepresenting that a particular security is suitable for a customer's investment objectives or from failing to disclose that a particular security is not suitable for a customer's objectives. ${ }^{17}$ Moreover, courts are likely to impose hability on securities salesmen when they find that a relationship of trust and confidence has developed between the broker and the customer. ${ }^{18}$ At the core of the legal regime regulating this relationship between securities firms and their customers is the so-called "suitability doctrine," which sets forth a general requirement that a securities salesman must have a reasonable basis for the recommendations made to custemers. Under the doctrine, the salesman must take the custemer's financial circumstances and investment objectives inte account when making his recommendations. ${ }^{19}$

Administrative Agency Obsolescence and Interest Group Formation: A Case Study of the SEC at Sixty, 15 Cardozo L Rev 909 (1994); David Haddock and Jonathan R. Macey, Regulation on Demand: A Private Interest Model, with an Application to Insider Trading Regulation, $30 \mathrm{~J} \mathrm{~L} \mathrm{\&} \mathrm{Econ} 311$ (1987).

${ }^{15}$ See C. Edward Fletcher III, Sophisticated Investors Under the Federal Securities Laws, 1988 Duke L J 1081, 1083-84.

${ }^{16}$ See, for example, O'Connor v R.F. Lafferty \& Co, 965 F2d 893, 898 (10th Cir 1992).

${ }^{17}$ See, for example, Brown v E.F. Hutton Group, Inc, 991 F2d 1020, 1031-32 (2d Cir 1993); Lefkowitz v Smith Barney, Harris Upham \& Co, 804 F2d 154, 155-56 (1st Cir 1986).

${ }^{18}$ See, for example, Vucinich v Paine Webber, Jackson \& Curtis, Inc, 803 F2d 454, 460 (9th Cir 1986).

19 The "suitability doctrine" finds its origins in the internal governance rules of the National Association of Securities Dealers, the New York Stock Exchango, and the Mu- 
The contrast between Partnoy's view of derivatives and that held by courts is reflected in the Fourth Circuit's recent holding in Banca Cremi $v$ Alex Brown \& Sons, Inc. ${ }^{20}$ Banca Cremi involved collateralized mortgage obhgations ("CMOs"), which are discussed extensively in F.I.A.S.C.O. (pp 219-33), and which Partnoy describes variously as "extremely risky," "misleading," "deceiving," and "especially dangerous," despite the fact that "they can appear quite safe" ( $p$ 220). Indeed, in Banca Cremi, the plaintiff, a Mexican bank, made the same sort of allegations against an American broker-dealer firm that Partnoy makes throughout F.I.A.S.C.O. The plaintiff bank maintained that it was an unsuspecting custemer, misled into thinking that CMOs in general were not risky and that they display trading patterns similar to other fixed-income securities like bonds, rather than to more volatile derivatives. Further, the Banca Cremi plaintiff alleged that the defendant failed to disclose precisely the sort of information about CMOs that Partnoy claims makes them so dangerous. In particular, Partnoy emphasizes the risks of prepayment, which make CMOs "so unpredictable" ( $p$ 220). Likewise, in Banca Cremi, the customer complained that the investment bank failed to provide information about how CMOs work, including information about prepayment and the effects of interest rate changes on the market value of CMOs.

This line of argument would have fooled Partnoy, but it did not fool the Fourth Circuit in Banca Cremi. In fact, the analysis of CMOs in Banca Cremi is far more nuanced and sophisticated than any of the analysis contained in F.I.A.S.C.O. First, unlike Partnoy, the court was able to comprehend the social utility of CMOs: "CMOs were designed to make home mortgage investments more attractive to institutional investers, increase the liquidity in the secondary home mortgage market, and reduce the interest costs to consumers buying homes." ${ }^{21}$ Second, the court understeod that some CMOs are far less risky than others, and thus did not commit Partnoy's error of treating all CMOs as highly risky. ${ }^{22}$ Third, the court in Banca Cremi seemed to understand, as Partnoy does not, that dissatisfied investors sometimes will resort to the securities laws to redress errors resulting not

nicipal Securities Rulemaking Board. See NASD Rules of Fair Practice, NASD Manual (CCH) 2310, IM 2310-2; New York Stock Exchange Rule 405, 2 NY Stock Exch Guide (CCH) Il 2405; MSRB Rule g-19, MSRB Manual, Exchange Act Rel No 33,869, 56 SEC Docket (CCH) 1062, 1064 (Apr 7, 1994).

${ }^{20} 132$ F3d 1017 (4th Cir 1997).

${ }^{21}$ Id at 1022.

2 Id at 1023. 
from fraud or a breach of fiduciary duty on the part of the investment bank but from the investor's own misjudgment. The court wisely observed that people should "invest carefully," and that "[a] dissatisfied investor cannot recover for a poor investment on the basis of a broker's alleged omission or misstatoment where, through minimal diligence, the investor should have discovered the truth. ${ }^{123}$ In other words, the court was aware that placing too heavy a burden on derivatives sellers would creato inefficiencies and market distortions by providing buyers with strong disincentives to educate themselves about the nature of their trading activities.

The court also drew a distinction between sophisticated investors and unsophisticated investors, realizing that, to recognize the risks of an investment and to discern when misrepresentations are being made, sophisticated investors need less information than unsophisticated investors. The court looked at the nature of the relationship between the investment bank and the customer to see if a relationship of trust and confidence had developed that would have entitled Banca Cremi to enjoy the benefits of the higher standard of care enjoyed by beneficiaries of fiduciary duties. The court concluded that it is possible for investment banks to deal at arms length with their institutional investor clients. ${ }^{24}$ As a result of the arm's length relationship between Banca Cremi and the American salesman, the salesman did not owe Banca Cremi a fiduciary duty, and the court explicitly refused to creato a new legal duty requiring a principal selling a security to "warn another principal that an investment may be imprudent or may not meet all of a buyer's investment goals. ${ }^{.25}$ As the Banca Cremi decision illustratos, courts, unlike Partnoy, do not simphistically view the world as divided between lawless securities firms and unwary investors, who are not only duped by these unscrupulous sellers but who also return repeatedly te the same firms for more abuse. A more realistic view of the relationship between investment firms and their customers is one that I have offered previously:

Well developed financial markets are an integral part of the economic life of every industrialized nation. Financial markets are the engine through which a society's capital is allocated and through which its investment decisions are made. The trading firms that have flourished over time are the

${ }^{23}$ Id at $1027-28$ (citation omitted).

${ }^{24}$ Id at 1030.

${ }^{25}$ Id at 1038. 
ones that have been able to keep credible commitments to investors-including the commitment to develop and maintain adequate systoms of intornal monitoring and control. ${ }^{26}$

\section{CONCLUSION}

It would be too easy to dismiss F.I.A.S.C.O. as a total waste of the reader's time. To its credit, the book contains some nice institutional details about the derivatives market. There is, for exainple, a very accessible description of options and forwards, which are the building blocks of derivatives, toward the beginning of the book (pp 30-32). But the vast bulk of F.I.A.S.C.O. is misleading or inaccurate. Partnoy does not convey any sense of the multitude of socially beneficial purposes that derivatives can provide to purchasers, and he fails to understand the strong incentives that motivato rational, survival-oriented firms like Morgan Stanley to discourage the opportunistic behavior that might give rise to the conduct F.I.A.S.C.O. maintains is endemic in the derivatives nidustry. Moreover, Partnoy displays a calculating lack of understanding of the environinent in which he briefly worked. My guess is that he read Liar's Poker and thought that he had found a successful formula for a best seller: an insider's depiction of a corrupt world of rich Wall Street insiders profiting at the expense of honest and hard-working, but unsophisticatod, outsiders.

There is, however, one important reason to read F.I.A.S.C.O.: it provides a window into the world of ill-informed, misleading analysis-by-way-of-anecdote that provides the predicato for much regulation. If someone wantod to regulate the derivatives market, F.I.A.S.C.O. provides the pretonse of a justification. But for an honest student of derivative markets, the book's sensationalism is only surpassed by its intollectual dishonesty. Partnoy tries very hard, for example, to create the impression that firms like Morgan Stanley are about to start peddling the sorts of complex derivative securities described in F.I.A.S.C.O. to unsuspecting members of the general pubhc. In the closing pages, for example, Partnoy writos that Morgan Stanley, "not content to sell sophisticated financial instruments te insurance companies and state pension funds, is now seeking out even less-sophisticated investors-you, for example-by agreeing to merge with Dean Witter" (p 251). Of course only a rather careful reader who comes to this book with some advanced knowledge of the securities industry

\footnotetext{
${ }^{25}$ Macey, $21 \mathrm{~J}$ Corp L at 93 (cited in note 4).
} 
will notice that 219 pages earher Partnoy distinguishes between the more hquid and more highly regulated derivatives that trade on organized exchanges-the kind that are available to small retail customers-and the more exotic privatoly negotiated overthe-counter derivatives that he is describing in this book ( $p 32$ ).

Upon reading F.I.A.S.C.O., it is more clear to me why regulation is so often built on sensationalism and faulty thinking rather than on careful analysis and genuine need. It is also evident why teaching economics to policymakers is so important. Economic analysis provides the tools necessary to see througl the misleading hyperbole of writers like Frank Partnoy. 


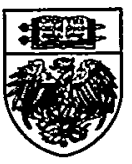

HeinOnline -- 65 U. Chi. L. Rev. 15121998 


\title{
We the Unconventional American People
}

\author{
James E. Fleming
}

\author{
We the People: Transformations. Bruce Ackerman. Harvard, \\ 1998. Pp vii, 515.
}

\section{INTRODUCTION: UNCONVENTIONAL TRANSFORMATIONS OF THE CONSTITUTION}

In his 1991 volume, We the People: Foundations, Bruce Ackerman urged us as Americans to declare our independence from European models of government and to "look inward" to rediscover our distinctive constitutional scheme-dualist democracy. ${ }^{1}$ In his new volume, We the People: Transformations, he exhorts us as dualist democrats to break up the monopoly that Article V of the Constitution has held on our vision of constitutional amendment. He urges us to move "beyond Article V" and to embrace a pluralist understanding of the sources of higher lawmaking (pp 15-17). Only by doing so, he argues, will we be able to comprehend the processes of unconventional adaptation outside Article V whereby We the People have transformed the Constitution through the Founding, Reconstruction, and New Deal. Nothing less, Ackerman admonishes us, will preserve and realize both "the possibility of popular sovereiguty" ( $p$ 119) and "the possibility of interpretation" under our Constitution. ${ }^{2}$ Thus, if Foundations celebrated American exceptionalism from Europe- "We the exceptional American People ${ }^{33}$-Transformations extols our unconventional adaptation and transformation of the Constitution outside Article V- We the unconventional American People."

$\dagger$ Professor of Law, Fordham University School of Law. Ph.D. 1988, Princeton University; J.D. 1985, Harvard University; A.B. 1977, University of Missouri. I am grateful to Mike Dorf, Martin Flaherty, Abner Greene, Nick Johnson, Linda McClain, and Ben Zipursky for helpful comments on a draft of this essay, and to Sot Barber, Chris Eisgruber, Ned Foley, Sandy Levinson, Frank Michelman, Larry Sager, and Bill Treanor for valuable discussions of Bruce Ackerman's constitutional theory. I benefited from presenting a draft at a Fordham University School of Law Faculty Work-in-Progress Colloquium.

1 Bruco Ackerman, We the People: Foundations 3-6, 32-33 (Harvard 1991).

2 Id at 131-62.

3 See James E. Fleming, We the Exceptional American People, 11 Const Comm 355 (1994) (analyzing Ackerman's constitutional theory in light of the tradition of "American exceptionalism" from European models). 
In the introduction to Transformations, Ackerman writes: "There is lots of history in this book, some pohtical science, a little philosophy-but these intordisciplinary excursions are in the service of a fundamentally legal enterprise: . . . If Americans of the 1990's wish to revise their Constitution, what are the legal alternatives they may legitimately pursue?" ( $p 28$ ). His formulation is telling, because the strengths of this magnificent and important volume lie in its history, which is ingenious and fascinating, and its pohtical science, which is sophisticatod and insightful, but the shortcomings he in its philosophy: its political, legal, and constitutional theory. As a matter of history and political science, Ackerman provides among the best analyses ever offered of the processes of constitutional transformation through the Founding and Reconstruction, and the best analogies ever drawn between those constitutional moments of higher lawmaking and the political transformation inaugurated by the New Deal. But as a matter of philosophy, he fails to sustain his argument that the model of transformation that he develops provides legal alternatives for legitimate amendment of the Constitution outside Article V. The "humanistic positivism" that he adumbratos to provide rules of recognition of higher lawmaking (as distinguished from ordinary lawmaking) (p 92) is not sufficient to estabhsh that the New Deal, by analogy to the Founding and Reconstruction, rises to the level of a constitutional amendment.

After describing Transformations' theory of unconventional constitutional change, I critique it in light of Ackerman's larger project in the projected three volume We the People, focusing on three of his pervasive claims or themes. First, despite Ackerman's claim that his theory of dualist democracy entails his account of transformation through unconventional adaptation, he elaborates that account in a manner that practically levels or reduces his dualism to a form of monism. Second, notwithstanding his suggestion that "the possibility of popular sovereignty" under our Constitution depends upon our accepting his theory of transformation to supplement or even override Article V's formal amending procedures, he has not developed a theory of popular sovereignty that is adequate to underwrite his theory of transformation, much less the Constitution. Nor has he shown the impossibility of a dualist constitutional theory that both gives due regard to popular sovereignty and views Article $\mathrm{V}$ as specifying the exclusive procedures for amending the Constitution. Third, despite Ackerman's clann that to preserve "the possibility of interpretation" of the Constitution we must accept his contention that the New Deal amended the Constitution, he has not put for- 
ward a theory of interpretation that can plausibly and elegantly justify our basic liberties and many of the leading cases since 1937 in terms of the New Deal republic. Moreover, his development of the model of transformation, which empliasizes the discontinuity between the republics constituted by the Founding, Reconstruction, and New Deal, may make it more difficult for him to provide interpretations that achieve "intergenerational synthesis" across republics in the projected third volume, We the People: Interpretations. ${ }^{4}$

Finally, in a concluding Section entitled "The Constitution Goes to Yale," I reflect upon Ackerman's claims regarding "the possibility of popular sovereignty" and "the possibility of interpretation." I basically turn those claims on their heads by asking: How is it possible that Ackerman, who is Sterling Professor of Law and Political Science at Yale and is undoubtedly in the pantheon of constitutional theorists, could believe it necessary to develop his theory of constitutional amendinent and transformation outside Article V in order to preserve and realize these possibilities? My speculation is that it must be because of something they put in the drinking water in New Haven. ${ }^{6}$ I suggest that the root difficulties in Ackerman's constitutional theory bear deep affinities te those in the work of his former Yale colleagne, Alexander M. Bickel ${ }^{7}$ (as well as those in the work of his current Yale colleagne, Akhil Reed Amar ${ }^{8}$ ). Bickel was haunted by the "countermajoritarian difficulty" that he thought judicial review posed in a democracy because he held an impoverished conception of our constitutional scheme as majoritarian representative democracy. Similarly, Ackerman is lobbled by the quest for "the possibility of popular sovereignty" because lie holds a richer, yet still reductive, conception of our constitutional scheme as popular sovereignty.

4 In both Volume I and Volume II, Ackerman refers to the projected Volume III, to be titled We the People: Interpretations. Ackerman, Foundations at 99, 118, 162 (cited in note 1); Ackerman, Transformations ( $\mathrm{p} \mathrm{403).}$

s In formulating the idea of "The Constitution Goes to Yale," I have been inspired by the title of a previous article about Harvard constitutional theorists. Henry P. Monaghan, The Constitution Goes to Harvard, 13 Harv CR-CL L Rev 117 (1978).

- See Akhil Reed Amar, The Consent of the Governed: Constitutional Amendment Outside Article V, 94 Colum L Rev 457, 457 (1994) (stating, concerning responses to his theory of constitutional amendment outside Article V, that "I suspected my audience might well wonder if someone had been messing with the drinking water in New Haven").

Tee Alexander M. Bickel, The Least Dangerous Branch: The Supreme Court at the Bar of Politics (Yale 2d ed 1986).

- See Amar, 94 Colum L Rev 457 (cited in note 6); Akhil Reed Amar, Philadelphia Revisited: Amending the Constitution Outside Article V, 55 U Chi L Rev 1043 (1988). 
As against the Yale school theorists, I contend that our Constitution is "incorrigible" or "irreducible" ${ }^{10}$ in the sense that it resists being reduced to either majoritarianism or popular sovereignty. To do justice to our Constitution, we need a dualist constitutional theory that conceives it as securing the basic hberties that are preconditions for self-government in two senses: not only deliberative democracy, whereby citizens apply their capacity for a concoption of justice to dehberating about the justice of basic institutions and social policies, as well as about the common good, but also deliberative autonomy, whereby citizens apply their capacity for a conception of the good to deliberating about and deciding how to live their own lives. ${ }^{11}$ Such a theory, unlike Ackerman's, would not transform our Constitution inte the mold of popular sovereignty.

\section{TRANSFORMATIONS OF THE CONSTITUTION THROUGH UNCONVENTIONAL HIGHER LAWMAKING}

\section{A. The Story Thus Far: Foundations}

In Foundations, Ackerman mapped the terrain of American constitutional theory as being divided into momists ("Anglophiles"), rights foundationalists ("Germanophiles"), and dualists (red-blooded Americans). ${ }^{12}$ Monism emphasizes popular sovereignty over and against fundamental rights, and thus tends to equate popular sovereignty with parliamentary supremacy on a British model. Rights foundationalism challenges the primacy of popular sovereignty, stressing constraints imposed by deeper commitments to fundamental rights on a German model. Ackerman presents dualism as an "accommodation" between monism and rights foundationalism. Dualism distinguishes between the constituent power of We the People, expressed in the higher law of the Constitution, and the ordinary power of officers of government, expressed in the ordinary law of legislation. Dualism preserves, against encroachment by ordinary law, the fundamental rights ordained and established by We the People in the higher

- See Lawrence G. Sager, The Incorrigible Constitution, 65 NYU L Rev 893 (1990) (arguing that our "incorrigible" justice-seeking Constitution resists being reduced to an expression of popular sovereignty).

${ }^{10}$ See Abner S. Greene, The Irreducible Constitution, 7 J Contemp Legal Issues 293 (1996) (arguing that our "irreducible" Constitution resists being reduced to either democracy or fundamental rights).

"See James E. Fleming, Securing Deliberative Autonomy, 48 Stan L Rev 1, 2-3, 17-29 (1995); James E. Fleming, Constructing the Substantive Constitution, 72 Tex L Rev 211, 217-20, 280-97 (1993).

${ }^{12}$ Ackerman, Foundations at 6-16, 32-33, 35-36 (cited in note 1). 
law of the Constitution; to that extent, it is like rights foundationalism. But it preserves only those fundamental rights; beyond them, it is like monism in deferring to ordinary law.

Ackerman argued that our dualist democracy has undergone three great constitutional "moments" of higher lawmaking: the Founding, Reconstruction, and New Deal. ${ }^{13}$ These moments inaugurated three regimes or repubhes within our Constitution: the early repubhic of the Founding Federalists, the middle republic of the Reconstruction Republicans, and the modern republic of the New Deal Democrats. Ackerman sketched the processes of transformation through each moment and the substance of the higher law of the Constitution during each republic. He argued that, in a dualist democracy, judicial review is justified on the ground that (and to the extent that) it preserves the higher law of the Constitution against encroachment by the ordinary law of legislation. ${ }^{14}$ Finally, in justifying dualist democracy, he analyzed its foundations in a political theory, grounded in popular sovereignty, tbat is a synthesis of the competing traditions of liberalism and republicanism. ${ }^{15}$

B. The Transformation of Dualist Democracy: Transformations

In Transformations, Ackerman elaborates upon the processes of transformation through the Founding, Reconstruction, and New Deal. He does not further develop the substance of the higher law of each republic; that presumably will follow in Interpretations. He begins by reframing the Founding (pp 32-68). He emphasizes that the Founding was a break with legality in the sense that it did not play by the rules of the system of higher lawmaking and amendment prescribed in the Articles of Confederation. The Continental Congress had authorized a constitutional convention to amend the Articles, not to draft a new Constitution, and the Articles had required that amendments be adopted by every state, whereas under the proposed new Constitution, adoption by nine statos out of thirteen was sufficient for ratification. He conceives the Founding in terms of processes of unconventional adaptation whereby the Federalists used existing institutions in new ways to earn the authority to speak for the People, distinguishimg five stages of unconventional activity: signaling, proposing, triggering, ratifying, and consolidating. $\mathrm{He}$ argues that this model of transformation, not compliance with pre-

${ }^{13} \mathrm{Id}$ at 58-80.

14 Id at 60-61, 72.

${ }^{15}$ Id at 29-33. 
scribed rules for amendment, accounts for the legitimacy of the constitutional change brought about through the Founding.

Ackerman then applies the precedent of the Founding to examine Reconstruction (pp 99-252). He argues that, in adopting the Thirteenth, Fourteenth, and Fifteenth Amendments, Reconstruction also broke with legality by not following the rules of the system of higher lawmaking and amendment specified in Article V. For example, Congress overrode southern states' rejections of the proposed Fourteentl Amendment, and conditioned each state's representation in Congress upon: (1) its adoption of that amendment, and (2) adoption of the amendinent by the threefourths of the states required for it te become a part of the Constitution. Again, Ackerman uses the five-stage model of transformation to illuminate the processes of unconventional adaptation wliereby Reconstruction Republicans earned the authority to transform the Constitution in the name of the People.

Finally, in rethinking the New Deal, Ackerman argues that it, by analogy to the Founding and Reconstruction, rises to the level of a constitutional amendment and transformation (pp 279311). He acknowledges that the New Deal did not satisfy the formal rules for amending the Constitution specified in Article V, but for him that fact is no more dispositive than is the fact that the Founding Federalists and Reconstruction Republicans did not play by the rules. On his view, the Founding and Reconstruction brouglit about legitimate constitutional change because they satisfied the criteria for revision developed in his five-stage model of transformation; for the same reason, so, teo, did the New Deal. Ackerman concedes that, lowever unconventional the Founding and Reconstruction were when measured against the prescribed rules for higher lawmaking, botll of those transformations did culminate in amendments to the text of the higher law. The New Deal, however, was unconventional not only in its processes but also in its outcome. It did not result in any amendments te the text of the Constitution, and so to gather the content of the New Deal transformation we must look te "transformative judicial opinions" (pp 26, 359-77). These opinions provide a text-analogue or the functional equivalent of a formal constitutional amendment. They established the constitutional permissibility of activist government in the regulatory and welfare state.

If the foils for dualism in Foundations were monism and rights foundationalism, the foil for unconventional adaptation in Transformations is Article $\mathrm{V}$ formalism or positivism: the view that Article $\mathrm{V}$ prescribes the exclusive procedures for amendimg the Constitution (pp 15-17, 28-31). As against Article V positiv- 
ists, Ackerman adumbrates a "humanistic positivism," which entails a pluralistic conception of the procedures for and sources of higher lawmaking ( $p$ 92). On his view, the "rules of recognition" for higher lawmaking, or criteria for legitimate constitutional revision, are not limited to the formal rules prescribed in Article V, but include the criteria elaborated in his five-stage model of transformation. And the sources of higher lawmaking include not only the rules of Article $V$ but also our principles, practices, and precedents (most importantly, the great precedents of higher lawmaking, the Founding and Reconstruction); in effect, he proposes a common law of higher lawmaking ( $p p$ 232, 383-84). And so, as against Article V formalism, which presumes that Article V channels all legitimate constitutional amendinent through its rules, Ackerman advances an understanding of unconventional adaptation and transformation according to which legitimate constitutional amendment occurs outside Article V.

Ackerman argues that Article $V$ positivists cannot account for the legitimacy of the constitutional change brought about through either the Founding or Reconstruction, because neither played by the formal rules laid down for amending the higher law. Only his model of transformation can do so. He also argues that Article V positivists cannot plausibly account for the legitimacy of the constitutional change during the New Deal. Having gained a foothold for his model of transformation in justifying the Founding and Reconstruction, he argues that it is also necessary te account for the New Deal. He contends that the same criteria for revision that estabhsh the Founding and Reconstruction as constitutional transformations also establish the New Deal as one.

Article V positivists, Ackerman contends, do not merely deny that the New Deal brought about a constitutional amendment and transformation. Worse yet, they cloak its constitutional creativity in the "myth of rediscovery" - the myth that the Supreme Court in 1937 and afterward rediscovered the original understanding of the Constitution as contemplated by Founding Federalists, most notably James Madison and John Marshall (pp 8-10, 259,279 ). This myth of rediscovery is troublesome not only because it obscures the foundations of the modern activist regulatery and welfare state inaugurated by the New Deal, but also because it denigrates the constitutional creativity of We the People, thus undermining the possibility of popular sovereignty in America. As against this view, Ackerman exhorts us te rediscover or reclaim the Constitution and to preserve the possibility of 
popular sovereignty through unconventional adaptation and transformation (pp 383-420). ${ }^{16}$

\section{The Transformation, AND LeVeling, of DuAlism}

As described above, Ackerman argned in Foundations that dualism offers a better account of our constitutional scheme than monism or rights foundationalism. Nonetheless, in the closing pages of that volume he called for moving "beyond dualism" to a rights foundationalist scheme that would entrench inalienable rights into our Constitution against subsequent amendment, ${ }^{17}$ prompting sone critics to wonder whether he was really a rights foundationalist. ${ }^{18}$ I shall take the opposite tack in criticizing Transformations, suggesting instead that Ackerman's theory of transformation itself transforms his theory of dualist democracy into a form of monism.

A. Reclaiming or Reconstructing the Classical, Interpretive Justification of Judicial Review

Constitutional theorists since Bickel-and Ackerman is no exception-have been troubled by the "counter-majoritarian difficulty" said to be posed by judicial review in a democracy. ${ }^{19}$ The classical, interpretive justification of judicial review, put forward in The Federalist 78 and Marbury $v$ Madison, purports to resolve this difficulty. ${ }^{20}$ On this view, courts are obligated to interpret the higher law of We the People enrbodied in the Constitution and to preserve it against encroachment by the ordinary law of officers of government embodied in legislation. Therefore, judicial review implies constitutional, not judicial, supremacy, or the supremacy of the People over their agents, the officers of government.

In recent years, narrow originalists like Robert Bork and Justice Antonin Scalia have claimed a monopoly on the classical, interpretive justification of judicial review. ${ }^{21}$ But Ackerman,

${ }^{16}$ Ackerman also calls for "reclaiming the Constitution" by reforming the higher lawmaking system through adopting a "Popular Sovereignty Initiative" by statute (pp 41016). I discuss this matter in note 33 .

${ }^{17}$ Ackerman, Foundations at 319-22 (cited in note 1).

${ }^{18}$ See, for example, Michael J. Klarman, Constitutional Fact/Constitutional Fiction: A Critique of Bruce Ackerman's Theory of Constitutional Moments, 44 Stan L Rev 759, 76364 n 37 (1992).

${ }^{19}$ See Bickel, The Least Dangerous Branch at 16-23 (cited in note 7); Bruce Ackerman, Discovering the Constitution, 93 Yale L J 1013, 1013-16 (1984).

${ }^{20}$ Federahist 78 (Hamilton), in Clinton Rossiter, ed, The Federalist Papers 467, 469 (Mentor 1961); Marbury v Madison, 5 US (1 Cranch) 137, 177-78 (1803).

${ }^{21}$ See Robert H. Bork, The Tempting of America (Free Press 1990); Antomin Scalia, A Matter of Interpretation (Princeton 1997). 
through his theory of dualism, has sought to reclaim that justification and to reconstruct it. ${ }^{22} \mathrm{He}$ has done so by arguing that higher lawmaking by We the People includes not only amendments to the Constitution adopted through the formal procedures of Article $\mathrm{V}$ but also unconventional adaptation and transformation of the Constitution outside Article V. He reconstructs the classical, intorpretive justification in the sense that judicial review under his theory is likewise justified as preserving the higher law of We the People (as he conceives it) against encroachment by the ordinary law of officers of government.

It is important to note that a constitutional theory can be dualist in a general sense without being dualist in Ackerman's specific sense. That is, a theory can insist upon maintaining the distinction between the constituent power of We the People and the ordinary power of officers of government without endorsing his complex apparatus of higher lawmaking outside Article V. For example, Ronald Dworkin's constitutional theory is dualist in this general sense and indeed Dworkin, like Ackerman, seeks to reclaim and reconstruct the classical, interpretive justification of judicial review. ${ }^{23}$ Dworkin does so by putting forward a theory of constitutional intorpretation-both a conception of What the Constitution is and a conception of How it should be interpretod $\mathrm{d}^{24}-$ that is an alternative to that of the narrow originalists. As for What, he argues that the Constitution embodies abstract moral principles, rather than enacting relatively concrete rules. As for How, he argues that interpreting and applying those principles requires fresh judgments of pohitical theory, rather than historical research to discover relatively specific original understanding or original meaning. He now calls this interpretive strategy the "moral reading" of the Constitution. ${ }^{25}$

\footnotetext{
${ }^{22}$ See Ackerman, Foundations at 60-61, 72 (cited in note 1); Ackerman, 93 Yale L J at 1046-51 (cited in note 19).

${ }^{23}$ See Ronald Dworkin, Freedom's Law: The Moral Reading of the American Constitution 72-83 (Harvard 1996); Ronald Dworkin, Life's Dominion 118-47 (Knopf 1993); Ronald Dworkin, Taking Rights Seriously 131-49 (Harvard 1977); Ronald Dworkin, The Arduous Virtue of Fidelity: Originalism, Scalia, Tribe, and Nerve, 65 Fordham L Rov 1249 (1997). For another powerful attempt to reclaim the classical, interpretive justification of judicial review from the narrow originalists, see Sotirios A. Barber, The Constitution of Judicial Power 157-58 (Johns Hopkins 1993); Sotirios A. Barber, Judicial Review and The Federalist, 55 U Chi L Rov 836, 836-39 (1988).

${ }^{24}$ These questions of What and How, along with the question of Who is to interpret?, are the basic interrogatives of constitutional interpretation. See Walter F. Murphy, James E. Fleming, and Sotirios A. Barber, American Constitutional Interpretation (Foundation 2d ed 1995).

${ }^{2 s}$ Dworkin, Freedom's Law at 1-38 (cited in note 23).
} 
The basic shortcoming of Ackerman's attempt to reclaim the classical, interpretive justification of judicial review is that, unlike Dworkin, he attempts to do so without advancing a theory of constitutional intorpretation as an alternative to that of the narrow originalists. To be sure, Ackerman develops an alternative conception of What the Constitution is-it includes not only higher law adopted through the formal amending procedures of Article $\mathrm{V}$ but also that ratified through unconventional adaptations and transformations outside Article V. But he does not advance an alternative understanding of How the Constitution should be interpreted. What Volume II, Transformations, provides is not a theory of interpretation-we must hope for that in the projected Volume III, Interpretations-but a model of transformation whereby political figures and movements earn the authority to speak in the name of We the People. In fact, Ackerman has not written anything in either Volume I or Volume II about intorpretation as a general theoretical matter. He promises to develop concrete interpretations in Volume III. ${ }^{26} \mathrm{I}$ return to this matter below, in assessing Ackerman's claim that the "possibility of interpretation" depends upon our accepting his theory.

\section{B. The Leveling of Ackerman's Dualism}

In Transformations, Ackerman does not make good on the claim that his theory of dualist democracy reclaims or reconstructs the classical, interpretive justification of judicial review. Instead, he develops that theory in a manner that may forfeit that justification and along with it his claim to be a dualist. For in Transformations, he practically levels his dualism to a form of monism (or perhaps super-monism).

As stated above, dualists in a general sense maintain a basic distinction between the higher law of We the People embodied in the Constitution and the ordinary law of officers of government embodied in legislation. On first sight, it might seem that almost every constitutional scholar in America is a dualist in this sense. Yet, to recall a torm that Ackerman used in Discovering the Constitution, before he coined the term "momsm," some constitutional scholars in effect "level" the higher law to the level of ordinary law. ${ }^{27}$ There are several ways that they do this. One approach is

${ }^{2}$ Ackerman states that "[w]hile interpretivists [who take interpretation seriously] have launched a jurisprudential counteroffensive [against 'realist banalities'] over the last decade," citing Ronald Dworkin, Law's Empire (Harvard 1986), he has "been on a different mission," that of "providing concrete interpretations of the constitutional past" ( $p$ 419).

${ }^{27}$ Ackerman, 93 Yale L J at 1035-38 (cited in note 19 ). 
to propose that judicial review should be extremely deferential to legislatures and executives, indeed so deferential that it levels the Constitution in the sense that for all practical purposes it does not limit legislation. James Bradley Thayer and Justice Felix Frankfurter are such levelers. ${ }^{28}$ Another way to level the higher law is to argue that it is exclusively or overwhelmingly concerned with securing procedural rights that are preconditions for the legitimacy of ordinary law as opposed to securing substantive rights that limit what government may do through ordinary law. Ackerman characterizes John Hart Ely as such a leveler. ${ }^{29}$

A third way to level the higher law of the Constitution is to suggest that higher lawmaking is not as fundamentally different from ordinary lawmaking as it initially appeared to be (when we characterized dualism as distinguishing two tracks of lawmaking). Ackerman proves to be a leveler in this sense. He does not make the general dualist argument that there are two distinct tracks of lawmaking-higher lawmaking through the procedures prescribed in Article $\mathrm{V}$ and ordinary lawmaking through the procedures prescribed in Article I. Instead, he makes the argument that we have two routes of higher lawmaking-one through following the procedures of Article $\mathrm{V}$ and another through engaging in pohtical activity that proceeds through the five stages of his model of transformation. The latter routo looks like an intormediate track of lawmaking, perhaps super-ordinary lawmaking through sustained, deep, and broad success in the electoral and legislative processes; hence my suggestion that Ackerman "levels" his dualism to a form of super-monism. ${ }^{30}$

${ }^{25}$ Ackerman, Foundations at 7, 11 (cited in note 1) (characterizing Thayer and Frankfurter as "monists"). See James Bradley Thayer, The Origin and Scope of the American Doctrine of Constitutional Law, 7 Harv L Rev 129 (1893); Minersville School District v Gobitis, 310 US 586 (1940) (Frankfurter, giving the opinion of the Court); West Virginia State Board of Education v Barnette, 319 US 624, 646 (1943) (Frankfurter dissenting) (objecting to the Court's overturning Minersville).

${ }^{20}$ Ackerman, 93 Yale L J at 1047-49 (cited in note 19), criticizing John Hart Ely, Democracy and Distrust (Harvard 1980).

${ }^{30}$ In characterizing Ackerman as a leveler, I do not mean to suggest that his theory of constitutional change invariably makes it easier to amend the higher law of the Constitution than does Article V. In fact, his theory is at once less and more denuanding than Article V. For example, the New Deal amended the Constitution according to Ackerman's theory despite the fact tbat it did not satisfy the requirements of Article V. Yet many of the formal amendments to the Constitution that have satisfied Article Vs requirenients, such as the Twentieth Amendment (changing the date of the end of the President's and Vice President's terms from March 4 to January 20), and the Twenty-Third Amendment (providing for electors of the President and Vice President from the District of Columbia), would not be able to satisfy Ackerman's criteria for revision. This should come as no surprise because Ackerman is offering criteria for legitimate constitutional transformation, whereas Article V specifies rules for mere amendment: the former is about fundamental 
The driving force behind Ackerman's leveling of dualism is his notion of popular sovereignty, which bridles at Article V's pretensions to rein it in. This point is nowhere more clear than in Ackerman's claim that, to realize the possibility of popular sovereignty, we must move beyond theories that stringently maintain the distinction between the two tracks of lawmaking to embrace a theory that acknowledges the unruly, unconventional ways in which the forces of popular sovereignty have transformed our higher law along with our higher lawmaking system. I take up this claim below.

Furthermore, Ackerman's theory of transformations practically levels popular sovereignty from constituent power to ordinary power (albeit ordinary power exercised in extraordinary circumstances or moments). The notion of popular sovereignty is noteriously ambiguous, mysterious, and vague, ${ }^{31}$ although it is not always acknowledged to be so in constitutional theory. Monists and dualists have very different conceptions of the notion of popular sovereignty. As conceived by monists, it refers basically to parliamentary supremacy on a British model, and it amounts to the ordinary power of officers of government engaged in passing the ordinary law of legislation in a majoritarian representative democracy. But popular sovereignty as conceived by dualists refers in the first instance te the constituent power engaged in dehberating about and adopting the higher law of the Constitution. ${ }^{32}$

When Ackerman initially sketches the foundations of dualist democracy, he seems to contemplate popular sovereignty in the latter sense. But by the time he elaborates upon the transformation to the New Deal, at the behest of popular sovereignty outside Article V, he seems practically te contemplate popular sover-

change, whereas the latter may be about revision of relatively insignificant admimistrative details.

${ }^{31}$ See Wayne D. Moore, Constitutional Rights and Powers of the People 90-99 (Princeton 1996) (analyzing some of the ambignities in the ideas of popular sovereignty and of "the people"); Frank I. Michelman, Always Under Law?, 12 Const Comm 227, 227 (1995) (characterizing the notion of popular sovereignty as having "an evocative or idealizing or quasi-mythical status"); Sager, 65 NYU L Rev at 902-09 (cited in note 9) (criticizing constitutional theories grounded in popular sovereignty). Ackerman claims to provide a "humanistic positivism" with "rules of recognition" for higher lawmaking by We the People, the popular sovereign, that is analogous to the sophisticated positivism developed by H.L.A. Hart in his classic work, The Concept of Law 70-76 (Oxford 1961). But Hart himself noted some of the difficulties and implausibilities of applying the notion of a "sovereign," which in theory must be free from all legal limitations, to a legal system such as that of the United States, in which the Constitution places legal limitations on legislative powers. Id at 71-78.

s2 See John Rawls, Political Liberalism 231 (Columbia 1993). 
eignty in the former sense. Admittedly, the popular sovereignty that he envisions is more sustained, deeper, and broader than that of the monist notion of popular sovereignty as parliamentary supremacy or majoritarian representative democracy. And it is popular sovereignty that expresses itself in extraordinary moments. But it is popular sovereignty that can exert itself unconventionally through elections rather than ratifying bodies, and through statutes and even judicial opinions rather than formal amendments. Therein lies the proof that Ackerman has leveled dualism. Indeed, for Ackerman, the People can even purport formally to amend the Constitution through a statute (pp 414-16). ${ }^{33}$ As compared with Ackerman, dualists who more rigorously maintain the distinction between higher lawmaking and ordinary lawmaking, along with that between constituent power and ordinary power, may liave a superior claim to be dualists and may be in a better position to reclaim and reconstruct the classical, interpretive justification of judicial review.

\section{From Positivism Without Law te Judicial Lawmaking Through Transformative Judicial Opinions}

That is not all. Ackerman also may forfeit his claim to be invoking the classical, interpretive justification of judicial review. Again, dualists resolve the "counter-majoritarian difficulty" by arguing that judicial review interpreting and preserving the higher law of the Constitution against encroachment by the ordinary law of legislation entails constitutional, not judicial, supremacy. Some critics of Foundations argued that Ackerman's dualism, and in particular his theory that the New Deal was a constitutional amendment, was an iromic instance of "legal positivism without positive law. ${ }^{134}$ That is, Ackerman claimed to be

${ }^{3}$ Ackerman proposes reform of the Constitution's higher lawmaking system through adopting a "Popular Sovereignty Initiative" by statute (pp 410-16). The Popular Sovereignty Initiative would authorize the President, upon reelection to a second term, to propose amendments te the Constitution in the name of the People. When approved by Congress, such proposals would be placed on the ballot at the next two Presidential elections rather than sent to the states for ratification. If a proposal gained popular approval through such a national referendum, it would be added to the Constitution. Ackerman also argues that the provision for the Popular Sovereignty Initiative itself should be adopted by these same procedures rather than through the procedures of Article $\mathrm{V}$ requiring ratification by the states.

The Popular Sovereiguty Initiative is in some senses more than an ordinary statute; Ackerman refers to it as a "special statute" ( $p$ 415). But it also illustrates a leveling of dualism in the sense that it provides for amendment of the Constitution in a manner that is more popular, and less removed from election returns and political mandates, than are the procedures of Article $V$.

${ }^{34}$ Richard A. Posner, Overcoming Law 215-28 (Harvard 1995) (criticizing Ackerman's 
developing a positivist theory that could estabhsh that the New Deal was a constitutional amendment, but his theory did not provide any higher law-a constitutional text or text-analogue-that constituted the amendment and that therefore could be interpreted and preserved against encroachment by ordinary law.

In Transformations, Ackerman puts forward the idea of "transformative judicial opinions" to fill in the content of the New Deal amendment (pp 26, 359-77). These opinions, written mostly between 1937 and 1942 by FDR's new appointees to the Supreme Court-the "transformative judicial appointees"-gave content to the New Deal transformation's general commitment to activist government in the regulatory and welfare state (or, more properly, estabhished the constitutional permissibility of such government). They rendered the considered political judgments of We the People, or popular sovereiguty, expressed through the electoral and political processes, into the vernacular of constitutional law. And in Ackerman's theory, these transformative judicial opinions supplied the deficiency of positivism without law, for they provided the law-the text-analogue-needed to specify the New Deal amendment to the Constitution. These opinions, as Ackerman puts it, are "the functional equivalent of formal constitutional amendments" (pp 26, 361).

Not so fast. This move may be available to some constitutional scholars, such as realists who believe that courts to some extent operate as a continually sitting constitutional convention. But it would seem not to be available to Ackerman, so long as he claims to be reclaiming or reconstructing the classical, interpretive justification of judicial review. For this move all but concedes that when judges engage in judicial review during constitutional moments, they are hterally making, rather than interpreting, the higher law ordained and estabhished by the Constitution. Constitutional scholars who are haunted by the "counter-majoritarian difficulty" dread the nightmare of judges functioning as the equivalent of a continually sitting constitutional convention. ${ }^{35}$ The classical, interpretive justification's response te the charge of judicial supremacy with the claim of constitutional supremacythat it is not the judges, but the Constitution in the name of We the People, who did it-can allay that dread only if in principle the content of the Constitution is something other than judicial

theory in Foundations in a chapter entitled "Legal Positivism without Positive Law").

${ }^{35}$ For the idea of the "nightmare" of judges never finding, but always only making, law, see H.L.A. Hart, American Jurisprudence through English Eyes: The Nightmare and the Noble Dream, in H.L.A. Hart, Essays in Jurisprudence and Philosophy 123, 126 (Oxford 1983). 
opinions. By advancing the notion that transformative judicial opinions provide the content of the higher law of the Constitution, Ackerman aggravates rather than allays that dread.

Ackerman no doubt would respond that the justices issuing transformative judicial opinions did so in the name of the higher law of the Constitution, as established through the New Deal amendment, which itself was ratified by We the People through the five-stage model of transformation. Thus, the justices spoke in those opinions in the name of the People after all, and they can put on the mantle of constitutional supremacy as distinguished from judicial supremacy. But this response loses plausibility when justices are interpreting election returns and pohtical mandates, and writing a constitutional text-analogue to codify them, rather than interpreting a text given to them (even if the text has an unconventional pedigree, as on Ackerman's account the Fourteenth Amendment does (pp 99-119)). For justices have no special competence in interpreting election returns and pohtical mandates, and in any event such political phenomena are unavoidably majoritarian.

\section{The Thinness of Ackerman's Dualism}

Our constitutional scheme is dualist not only in the general sense just analyzed but also in the substantive sense that it is a synthesis of the conflicting traditions of civic republicanism and hiberalism. This conflict is encapsulated in Benjamin Constant's famous contrast between the tradition associated with JeanJacques Rousseau, which gives primacy te the liberties of the ancients, such as the equal pohtical hiberties and the values of public life, and the tradition associated with John Locke, which gives greater weight to the liberties of the moderns, such as hiberty of conscience, certam basic rights of the person and of property, and the rule of law. ${ }^{36}$ Many constitutional theorists, including Ackerman, have offered their theories as syntheses of these two traditions. I have suggested elsewhere that certain liberals have coopted the revival of the republican tradition by constructing syntheses that have yielded thinner accounts of repubhicanism than one might have expected and than republicans inight have hoped

${ }^{36}$ Rawls, Political Liberalism at 4-5, 299 (cited in note 32), referring to Benjamin Constant, Liberty of the Ancients Compared with that of the Moderns (1819), in Benjamin Constant, Political Writings 307 (Cambridge 1988) (Fontana trans). Locke's most significant work in this respect is John Locke, Two Treatises of Government (Cambridge 2d ed 1967) (Peter Laslett, ed), and Rousseau's is Jean-Jacques Rousseau, On the Social Contract (St Martin's 1978) (Roger D. Masters, ed, and Judith R. Masters, trans). 
for. ${ }^{37}$ Frank Michelman and Cass Sunstein are the inost obvious cases in point. ${ }^{38}$ But Ackerman too is a liberal who has gotten on this bandwagon, calling his theory a "liberal republicanism," and his synthesis is thinner still.

For one thing, Ackerman's version of a liberal republicanism is more a "cycle" or rotation between liberalism and republicanism than a synthesis of them. During periods of ordinary politics, we have liberalism (as Ackerman puts it, we are private citizens), and during moments of constitutional politics and periods of transformation, we turn to republicanism (as lie puts it, we are private citizens), ${ }^{40}$ rather than lraving a synthesis of hberalism and republicanism both in ordinary politics and in constitutional politics. For another, the liberalism in play in Ackerman's dualism is quite thin. It is basically liberalism as conceived by interest-group pluralists like Robert $\mathrm{Dahl}^{41}$ rather than liberalism as conceived by liberal repubhicans or deliberative democrats like Michelman and Sunstein. Unlike the latter theorists, Ackerman does not advance a conception of deliberative democracy that requires government to provide public-regarding reasons concerning the common good for its actions, even in ordinary politics, and that forbids government from acting solely on the basis of the self-interested preferences of well-organized private groups or individuals. What is more, the republicanism in play in his theory is also quite thin. He seems to conceive republican selfgovernment entirely in terms of deliberation about the content of the higher law rather than in torms of deliberation about the common good in adopting ordinary law. ${ }^{42}$

A richer and better synthesis of these competing traditionsor substantive dualism-would conceive both ordinary pohtics and the content of the higher law of the Constitution as syntheses

${ }^{37}$ James E. Fleming and Linda C. McClain, In Search of a Substantive Republic, 76 Tex L Rev 509, 548-49 (1997).

${ }^{33}$ For Michelman's synthesis of these two traditions, see, for example, Frank I. Michelman, Law's Republic, 97 Yale L J 1493, 1524-32 (1988); Frank I. Michelman, The Supreme Court, 1985 Term-Foreword: Traces of Self-Government, 100 Harv L Rev 4, 3647 (1986). For Sunstein's synthesis, see, for example, Cass R. Sunstein, The Partial Constitution 133-41 (Harvard 1993); Cass R. Sunstein, Beyond the Republican Revival, 97 Yale L J 1539, 1566-71 (1988).

${ }^{39}$ Ackerman, Foundations at 29-33 (cited in note 1).

${ }^{40}$ Id at 31-32 (describing a "recurring cycle of normal, then constitutional, then normal politics" or "cyclical pattern" between liberal normal politics and republican constitutional pohtics).

"See id at 230-65. Dahl has provided one of the classic accounts of American democracy in terms of interest-group pluralism. See Robert A. Dahl, A Preface to Democratic Theory (Chicago 1956). I concede that there are differences between Ackerman's vision of normal politics and Dahl's conception of interest-group pluralism.

${ }^{42}$ Ackerman, Foundations at 266-94 (cited in note 1). 
of hiberalism and repubhicanism. Elsewhere, I have argued for a constitutional theory within which both ordinary politics and constitutional politics are sucl syntheses. It combines a "repubhican" theme of securing the basic liberties that are preconditions for deliberative democracy (or the liberties of the ancients), with a "liberal" theme of securing the basic liberties that are preconditions for deliberative autonomy (or the liberties of the moderns). ${ }^{43}$ Such a theory provides the basis for a richer form of dualism than Ackerman's.

\section{THE POSSIBILITY OF POPULAR SOVEREIGNTY}

Is Article $V$ of the Constitution a fixed point-or foundational text-that any constitutional theory, including those grounded in popular sovereignty, must he able acceptahly to fit and justify? $O x$ is Article $\mathrm{V}$ a pox upon the Constitution that any theory of popular sovereiguty worthy of invoking the name We the People should seek to limit and contain, if possible, by supplementing or even overriding it? ${ }^{44}$ Is it possible to articulato a constitutional theory that gives due regard to popular sovereignty but that also takes Article V seriously as prescribing the exclusive procedures for amending the Constitution?

Ackerman contonds that "the possibility of popular sovereiguty" under our Constitution depends upon our accepting his theory of unconventional adaptation and transformation outside Article V (p 119). ${ }^{45}$ What does he mean by this claim? He seems to be making both a justificatory claim and a hortatory claim. The justificatory claim is that our Constitution-notwithstanding the text of Article V in the Constitution itself-presupposes a theory of popular sovereignty in light of which Article $V$ is incomplete, a compromise, or even a mistake (if it purports to prescribe the exclusive procedures for making higher law). Therefore, in order for the Constitution to be able to realize its commitment to popular sovereiguty, and indeed for it to be legitimate, We the People must be free to amend and transform it outside the formal procedures of Article $\mathrm{V}$, including through the model of transformation that Ackerman develops. Otherwise, we are not a properly selfgoverning People.

${ }^{43}$ Fleming, 48 Stan L Rev at 25 (cited in note 11); Fleming, 72 Tex L Rev at 249-50, 252-53 (cited in note II).

"For the suggestion, in a Symposium on "Constitutional Stupidities," that Article V is the stupidest provision in the Constitution, see Stephen M. Griffin, The Nominee is . . . Article V, 12 Const Comm 171 (1995).

is The particular formulation, "the possibility of popular sovereignty," occurs on page 119 , but the claim or theme is pervasive throughout the entire volume. 
The hortatory claim is that We the People are more likely to live up to the rights and responsibilities of self-government if we beheve that the People, as recently as the New Deal, rose to the occasion of transforming the higher law of the Constitution. After all, if We the People have done so only once (or perhaps twice) in American history, and not since the Founding (or possibly Reconstruction) at that, what is the loope of the People accomplishing anything great by way of higher lawmaking in our time? Other theories, including those of Article $V$ exclusivity, denigrato the constitutional creativity of We the People, and thus may demoralize or debilitate the People, undermining the possibility of popular sovereignty.

To these claims, I offer three responses. First, through advancing the idea that "the possibility of popular sovereignty" requires us to supplement or even override Article V, Ackerman proves in Transformations to be a popular sovereignty-perfecting theorist. That is, he is arguing that the Constitution presupposes a theory of popular sovereignty in light of which Article V-evidently a fixed point or foundational text-can be seen to be incomplete, a compromise, or even a mistake. And he is arguing for interpreting the Constitution so as to perfect it from the standpoint of his theory of popular sovereignty, even to the point of supplementing or overriding provisions of its toxt. In torms of Dworkin's well-known formulations, Ackerman is calling for interpreting the Constitution so as to make it the best it can be and putting forward a "moral reading" of the Constitution. ${ }^{46}$

To suggest that Ackerman's theory, notwithstanding his strenuous and strained efforts in Foundations to differentiate it from theories like Dworkin's, ${ }^{47}$ reflects a moral reading of the Constitution is certainly not to say that it is wrong or incolerent. Indeed, elsewhere I lave advanced what I call a "Constitutionperfecting theory, ${ }^{, 48}$ which reflects a moral reading. Rather, it is

${ }^{46}$ See Dworkin, Freedom's Law at 1-38 (cited in note 23) (proposing an interpretive strategy called the "moral reading" of the Constitution). See also Ronald Dworkin, A Matter of Principle 146-66 (Harvard 1985) (arguing for interpreting a legal text such as the Constitution so as to make it the best it can be); Dworkin, Law's Empire at 176-275 (cited in note 26) (same).

${ }^{47}$ Ackerman, Foundations at 10-16, 32-33 (cited in note 1) (differentiating his own theory of dualist democracy from a theory of "rights foundationalism" that he attributes to Dworkin in such works as Dworkin, Taking Rights Seriously (cited in note 23), and Dworkin, Law's Empire (cited in note 26)). Elsewhere, I have analyzed Ackerman's attempt to differentiate his theory from theories hike Dworkin's. See James E. Fleming, Fidelity to Our Imperfect Constitution, 65 Fordham L Rov 1335, 1336-38, 1344-55 (1997); Fleming, 11 Const Comm at 366-68 (cited in note 3).

${ }^{46}$ Fleming, 65 Fordham L Rev at 1338, 1344-55 (cited in note 47) (endorsing and defending the idea of the moral reading); Fleming, 48 Stan L Rev at 15-16 (cited in note 11) 
to suggest that Ackerman's own development of his theory shows that we should assess it on different grounds than he initially offered it. Applying Dworkin's distinction between two dimensions of best interpretation, fit and justification, ${ }^{49}$ he had asserted that "fit is everything" and thus had inuplied that there was no need te resort to the dimension of justification in deciding which of the available competing theories provides the best account of our constitutional scheme. He had submitted that only his theory of dualist democracy and popular sovereignty-as against theories like Dworkin's-could fit the text of the Constitution and our constitutional experience. ${ }^{51}$ Adimittedly, Ackerman would respond that his theory provides the best interpretation of our constitutional scheme-as a matter of justification as well as fit-but to sustain that claim he would need to offer a fuller justification for dualist democracy and popular sovereignty than he has provided thus far.

Second, Ackerman does not show the impossibility of-or give sufficient attention to the possibility of - a constitutional theory that both gives due regard to the claims of popular sovereignty and takes Article V seriously as a fixed point of the Constitution that any constitutional theory must be able acceptably to fit and justify. Here, I sketch a dualist constitutional theory that does so. The claims of popular sovereignty certainly have a place, and carry great weight, in constitutional theory, but not the place or the weight that Ackerman gives them. Our Constitution's commitment te popular sovereignty is not incompatible with Article $\mathrm{V}$ exclusivity. Our constitutional scheme is dualist in a general sense-it prescribes distinct tracks for higher lawmaking and for ordinary lawmaking-and our commitment to popular sovereignty is expressed through and limited by Article V's procedures for higher lawmaking. On this view, We the People ordained and estabhished the Constitution, and from time to time have amended it, and thus the Constitution manifests popular sovereignty. But the Constitution also constitutos a scheme of government and a charter of principles that seek to establish justice and to express the fundamental commitinents and highest

(arguing for a "Constitution-perfecting theory"); Fleming, 72 Tex L Rev at 214 \& n 15 (cited in note 11) (same).

"For examples of Dworkin's formulations of the two dimensions of best interpretation-fit and justification-see Dworkin, Law's Empire at 239 (cited in note 26); Dworkin, A Matter of Principle at 143-45 (cited in note 46); Dworkin, Taking Rights Seriously at 107 (cited in note 23).

${ }^{s}$ Bruce Ackerman, Remarks at the New York University School of Law Colloquium on Constitutional Theory (Nov 16, 1993) (colloquy between Ackerman and Dworkin).

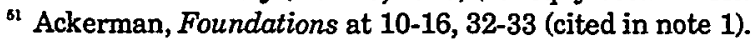


aspirations of a people. ${ }^{52}$ Once a workable Constitution of principle is in place, living under it, and interpreting it with integrity so as to make it the best it can be, carry their own imperatives. We should interpret the Constitution, both inside and outside the courts, so as to secure the basic liberties that are the preconditions for the legitimacy and trustworthiness of political decisions in our constitutional democracy. In justifying interpretations of it, we need not always make recourse to the fount of popular sovereignty. For our Constitution expresses commitments and aspirations besides popular sovereignty, and it may be legitimate and trustworthy for reasons other than conformity to popular sovereignty.

Ackerman is in the grip of an assumption or premise that the fundamental value or point of our Constitution and our democracy is a commitment to popular sovereignty. ${ }^{53}$ This premise undergirds a popular sovereignty conception of democracy that is not true to our scheme of government and that indeed obscures the true character and importance of our system. Instead, our Constitution reflects and presupposes a constitutional conception of democracy (or constitutional democracy) that conceives the fundamental point or value of our democracy to be concern for securing for everyone the status of free and equal citizenship. ${ }^{54}$ Within such a dualist constitutional democracy, securing the preconditions for self-government requires not merely preserving the possibility of popular sovereignty. It requires securing the basic liberties that are preconditions for self-government in two senses: not ouly deliberative democracy but also dehberative autonomy. ${ }^{55}$

\footnotetext{
${ }^{82}$ For conceptions of the Constitution along these lines, in terms of a "justice-seeking" account, as against conceptions of it in terms of popular sovereignty and backward-looking "instruction-taking," see, for example, Lawrence G. Sager, The Betrayal of Judgment, 65 Fordhain L Rev 1545 (1997); Lawrence G. Sager, Justice in Plain Clothes: Reflections on the Thinness of Constitutional Law, 88 Nw U L Rev 410 (1993); Sager, 65 NYU L Rev 893 (cited in note 9); Lawrence G. Sager, Democracy and the Justice-Seeking Constitution, paper presented at the New York University School of Law Colloquium on Constitutional Theory (Apr 24, 1997) (unpublished manuscript, on file with U Chi L Rev); Sotirios A. Barber, Justice-Seeking Constitutionalism and Its Critics, paper presented at the New York University School of Law Colloquium on Constitutional Theory (Apr 20, 1995) (unpublished manuscript, on file with U Chi L Rev).

${ }^{83}$ For a similar critique of the "majoritarian premise" undergirding majoritarian conceptions of democracy, and an argument for a constitutional conception of democracy, see Dworkin, Freedom's Law at 15-18 (cited in note 23).

4 See Fleming, 48 Stan L Rev at 3, 20 (cited in note 11); Fleming, 72 Tex L Rev at 253, 296-97 (cited in note 11). I have noted that this conception of constitutional democracy is similar te what Dworkin calls a "constitutional conception of democracy." See Fleming, 65 Fordham L Rev at 1342 (cited in note 47), discussing Dworkin, Freedom's Law at 17 (cited in note 23).

${ }^{55}$ See Fleming, 48 Stan L Rev at 2-3, 17-29 (cited in note 11); Fleming, 72 Tex L Rev
} 
From the standpoint of a dualist theory of constitutional democracy, it would be inapt to criticize Article V (or the Constitution generally) for its failure to conform to a deeper, richer, or more thoroughgoing commitment to popular sovereignty. Only a leveler who was in the grip of a different theory of popular sovereignty than that which the Constitution reflects and presupposes would make such a criticisin. A dualist who understood the character of the higher law of our Constitution and the commitments of our constitutional democracy would not reduce our constitutional scheme into a manifestation of popular sovereignty, or transform it in the image of popular sovereignty.

In support of Article $V$ exclusivity in such a dualist scheme, I would say two things. For one thing, I would give two cheers for Article $\mathrm{V}$ in a defensive sense, for it has protected the Constitution and its citizens against the recent rash of "amendmentitis. Numerous illiberal and ill-conceived amendments that would erode basic liberties or limit important powers have been introduced in Congress in recent years: the Flag Burning Amendment, the Balanced Budget Amendment, the Parental Riglits Amendment, the Religious Freedom Amendment, and the Human Life Amendment, to name a few. Despite the claims of representatives and senators in Congress to have a mandate from the People, all of the measures that have come up for a vote have failed to secure the two-thirds vote of both houses required by Article $V$ to propose an amendment for ratification by the statos. Article V's requirements have protected the Constitution and its citizens from such measures. ${ }^{57}$

For another, there is unuch to be said for Article $V$ in an affirmative sense. As Lawrence Sager has cogently argned, the obduracy of Article $V$ to ready and easy amendment of the Constitution lias encouraged and fostered broad interpretation of the Constitution's rights-protecting and power-conferring provisions. ${ }^{58}$ It

at 217-20, 280-97 (cited in note 11).

${ }^{6}$ See Kathleen M. Sullivan, Constitutional Amendmentitis, Am Prospect 20 (Fall 1995) (criticizing the recent rash of proposals to amend the Constitution).

${ }^{87}$ I acknowledge that Article V's requirements also have made it difficult to secure adoption of amendments that would secure hasic liberties, such as the Equal Rights Amendment. But the Equal Protection Clause of the Fourteenth Amendment should be interpreted to secure equal citizenship for women.

ss Sager, Democracy and the Justice-Seeking Constitution (cited in note 52); Lawrence G. Sager, The Birth Logic of a Democratic Constitution, paper presented at the New York University School of Law Colloquium on Constitutional Theory (Feb 9, 1995) (unpuhhshed manuscript, on file with $U$ Chi L Rev). I should make clear that although I would defend Article $\mathrm{V}$ affirmatively for its super-majority requirements for amending the Constitution, I would argue that a provision for ratification of a proposed amendment by a supermajority of the people of the United States is more defensible than Article V's provisions 
has underscored the character of the Constitution as a charter of majestic generalities and abstract principles as opposed to a code of relatively specific original understandings. Thus, Article $V$ has underwritten approaches to constitutional interpretation like those of Dworkin's moral reading, Sager's justice-seeking constitutionalism, and my own Constitution-perfecting theory. And such approaches to intorpretation are appropriato in a dualist scheme of constitutional democracy of the sort sketched above. Unfortunately, Ackerman does not seriously engage such arguments. ${ }^{59}$ Worse yet, his theory of amendment and transformation seems to presuppose a remarkably (and uncharacteristically ${ }^{60}$ ) narrow view of interpretation: that interpretation does not countenance change, and therefore that change may occur only through amendment. I return to this issue below.

Third, Ackerman's theory of popular sovereiguty and transformation meets with difficulty in fitting and justifying our dualist constitutional scheme. Our constitutional order cannot be reduced to a scheme of popular sovereiguty, nor can our basic hiberties (and leading cases interpreting them since 1937) be reduced to the structure of the modern republic brought about by the transformation to New Deal Democracy.

Ackerman's popular sovereiguty-perfecting approach to interpreting the Constitution bears a family resemblance te representation-reinforcing or process-perfecting theories such as those of Ely and Sunstein. ${ }^{61}$ Elsewhere, I have criticized the architecture of the latter theories, which attempt te frame or recast all of our basic liberties, both substantive and procedural, as precondi-

regarding ratification by three-fourtbs of the states (an argument with which Ackerman would presumably agree, see pp 410-16).

${ }^{80}$ Ackerman stated in colloquy with Sager at a recent symposium that Sager's article, 65 NYU L Rev 893 (cited in note 9), posed a "great question": "whether [Ackerman's] model is compatible with the abstract character of the constitutional enterprise." He continued: "Larry [Sager], I read your article several times, I should assure you. But I have to think more about it." Fidelity as Synthesis: Colloquy, 65 Fordham L Rev 1581, 1582 (1997) (colloquy between Ackerman and Sager). Yet in Transformations, Ackerman does not address Sager's arguments.

${ }^{60}$ I say that Ackerman's theory of amendment seems to presuppose an "uncharacteristically" narrow view of interpretation in light of the fact that Ackerman is often characterized as a "broad originahist," see note 74 , and that he elsewlere has written about interpretation in terms of the Constitution's highly abstract provisions regarding rights and powers, or its "liberating ahstraction." Bruce Ackerman, Liberating Abstraction, 59 U Chi L Rev 317 (1992).

${ }^{61}$ See Ely, Democracy and Distrust at 87-104 (cited in note 29) (advancing a "representation-reinforcing" theory of judicial review); Sunstein, The Partial Constitution at 142-44 (cited in note 38 ) (advancing a theory of judicial review whereby courts principally should secure the procedural preconditions for deliberative democracy). 
tions for representative or deliberative democracy. ${ }^{62} \mathrm{I}$ have argued instead for a Constitution-perfecting theory with two fundamental themes, which would reinforce not only the procedural liberties (those associated with deliberative democracy), but also the substantive hiberties (those related to dehberative autonomy) embodied in our Constitution.

My critique of the architecture of theories like Ely's and Sunstein's applies with some force to the architocture of Ackerman's theory, which reduces our Constitution to a manifestation of popular sovereiguty, and recasts its provisions so as to secure the preconditions for popular sovereiguty. For example, whereas Ely and Sunstein reject the substantive liberties like privacy or autonomy at issue in cases like Griswold $v$ Connecticut ${ }^{63}$ and Roe $v$ Wade, ${ }^{64}$ or recast them in procedural terms, Ackerman attempts to justify such hiberties and cases in torms of We the People's transformation of the Constitution through the New Deal. ${ }^{65}$ In particular, I would emphasize two reasons for the superiority of a Constitution-perfecting theory with the foregoing two themes. The first reason is architectonic: presenting our basic hberties in terms of dehberative democracy and dehberative autonomy illustrates that these two fundamental themes are co-original and of equal weight, and that neither is foundational. ${ }^{66}$ For both themes derive from a common substrate: a conception of citizens as free and equal persons (with two moral powers corresponding to the two themes) and a conception of society as a fair system of social cooperation. Both themes are constitutive of and articulato preconditions for the legitimacy and trustworthiness of political decisions in our constitutional democracy. Our Constitution resists being reduced to an expression of popular sovereiguty, just as it resists being recast into the mold of representative or deliberative democracy.

The second reason is elegance: the importance of being elegant (though not too reductive) in constructing a constitutional theory. Ackerman's theory, ironically, is not only reductive in the way just discussed but also inelegant. By his own self-deprecating characterization, it may appear to be an "unworkable Rube Goldberg contraption. ${ }^{37}$ To be sure, our constitutional scheme is com-

2 See Fleming, 48 Stan L Rev at 27-29 (cited in note 11); Fleming, 72 Tex L Rev at 233-38, 256-60 (cited in note 11 ).

381 US 479 (1965).

4 410 US 113 (1973).

${ }^{65}$ See Ackerman, Foundations at $150-59$ (cited in note 1 ).

${ }^{65}$ See Fleming, 48 Stan L Rev at 28 (cited in note 11).

" Ackerman, Foundations at 61 (cited in note 1). 
plex, and may require complex theories to account for it. But a Constitution-perfecting theory, with the two fundamental themes of dehiberative democracy and deliberative autonomy, can more elegantly, straightforwardly, and plausibly account for our dualist constitutional scheme than can Ackerman's theory. Furthermore, the fact that the apparatus of Ackerman's theory is quito unwieldy is troublesome given his hortatory claims for it. It may be more effective to advance a hortatory constitutionalism that can appeal directly to our aspirational principles of liberty, equality, and justice in addition to democracy, rather than to deploy a framework that may garble the exhortations because it always has to reconceive them in torms of the touchstone of popular sovereignty. Because Dworkin's moral reading of the Constitution, Sager's justice-seeking constitutionalism, and my own Constitution-perfecting theory can appeal directly to such aspirational principles, they may be more effective in supporting a comprehensible hortatory constitutionalism than is Ackerman's theory.

Finally, our basic liberties (and leading cases interpreting them since 1937) cannot be reduced to a inanifestation of popular sovereignty or justified in terms of the structure of the modern New Deal republic. We might concede to Ackerman that the New Deal was the last fundamental transformation of the Constitution (in a general sense, not in Ackerman's specific sense of amending the Constitution) and also grant that he is right that the purported Reagan Revolution failed to bring about a transformation (pp 389-403), yet still be unable to justify much of contemporary constitutional law in terms of the transformation to New Deal Democracy and the fundamental commitments of the inodern New Deal republic. (I return to this point in assessing Ackerman's claim about "the possibility of interpretation.") This is not to say that we do not need an account of the pohtical transformation wrought hy the New Deal to get us to where we are today. Rather, it is to say that we need more than the New Deal transformation to do so. We need a theoretical structure that will go beyond that transformation and beyond popular sovereignty to provide a substantive account of our scheme of basic liberties. In short, we need a dualist constitutional theory of the sort I have sketched.

\section{THE POSSIBILITY OF INTERPRETATION}

Ackerman also suggests that to preserve or realize "the possibility of interpretation" of our Constitution-as opposed to a realist vision of judicial lawmaking-we must accept his theory of 
amendment and transformation outside Article V. He stated this claim in Foundations, ${ }^{68}$ alludes to it in Transformations (p 419), and promises to elaborate upon it in Interpretations. ${ }^{69}$ But the claim should be assessed here, because it exposes a fundamental shortcoming in Ackerman's theory: He does not put forward a theory of intorpretation!

I daresay that Ackerman's failure to develop a theory of interpretation inay help to explain why he develops a theory of amendment outside Article V. That is, if Ackerman had a broad conception of interpretation, he would not need such a theory of amendment. Along similar lines, some critics have suggested that Ackerman's project reflects a remarkably narrow view of interpretation: ${ }^{70}$ that interpretation does not countenance change; therefore, change may occur only through amendment; hence, for the Constitution to be interpretable after the change brought about during the New Deal, it must have been amended through the New Deal.

Furthermore, despite Ackerman's claim about "the possibility of interpretation," it is impossible, plausibly and elegantly, to justify our basic liberties and many of the leading constitutional law decisions sinco 1937 in terms of popular sovereignty and the New Deal transformation. In fact, the cases that Ackerman analyzes in Foundations in connection with "the possibility of intorpretation ${ }^{971}$-Brown $v$ Board of Education and Griswold $v$ Connecticut-are difficult to justify in these terms. It is more straightforward to justify those decisions in terms of equal citizenship and privacy than in terms of the transformation to the activist regulatory and welfare state. The point is not simply that those casesand many others that follow, including Planned Parenthood $v \mathrm{Ca}$ sey ${ }^{72}$ - seem far afield from the transformation to the New Deal, but also that the accounts Ackerman offers of them are far less elegant and apt than other available accounts.

Id at 131-62. Ackerman had previewed this idea in Ackerman, 93 Yale L J at 107072 (cited in note 19).

Ackerman, Foundations at 162 (cited in note 1) (referring to projected Volume III, Interpretations).

${ }^{70}$ Sunstein also has charged that Ackerman's theory of amendment presupposes an "unduly rigid view of interpretation." Cass R. Sunstein, New Deals, New Republic 32, 35 (Jan 20, 1992).

"Ackerman, Foundations at 131-62 (cited in note 1), analyzing Brown $v$ Board of Education, 347 US 483 (1954), and Griswold v Connecticut, 381 US 479 (1965).

72505 US 833 (1992). Ackerman briefly analyzes Casey in Transformations (pp 397402). He does not give a full account of that case, or the right to abortion, in relation to the New Deal transformation. Rather, he focuses on "Casey's claracterization of the situation in 1937" (p 399). 
Ackerman presumably will say more about interpretation, if not put forward a theory of interpretation, in the projected Volume III, Interpretations. Here I want to suggest that Ackerman's presuppositions about interpretation in Transformations may pose or aggravate difficulties for his development of a theory of interpretation and advancement of concrete interpretations in Interpretations. For Volume II's model of transformations-and the underlying conception of three republics constituted by the Founding, Reconstruction, and the New Deal-emphasizes the discontinuity between each republic, and presumably the discontinuity between the substance of the higher law of the Constitution for each republic. Yet in Volume III, Ackerman will quest for fidelity as "intergenerational synthesis, ${ }^{, 73}$ or synthesis across generations or republics, notwithstanding the discontinuity that he himself has emphasized. (Ackerman is sometimes viewed as a "broad originalist," and and so presumably the notion of intergenerational synthesis will have a broad originalist cast to it.) Thus, Ackerman's account of transformations, to the extent that it overstatos discontinuity, may make it more difficult for him credibly to develop intorpretations that achieve such synthesis than if he had a theory of interpretation that could acknowledge change without casting it as amendment or transformation.

Ackerman criticizes constitutional theories that, instoad of seeing the New Deal as an amendment or transformation, cloak its creativity in the "myth of rediscovery" - the myth that the Supreme Court in 1937 and afterward rediscovered the original understanding of the Constitution as contemplated by the Founding Federalists (pp 10, 259, 279). And he presents such myths as efforts to deny constitutional creativity. Yet Ackerman overlooks the fact that what generate myths of rediscovery are theories of originalism, includimg broad originalist theories like his own. For originalists, both narrow and broad, believe that the only way to be faithful to the Constitution is to follow or translate original

${ }^{73}$ Ackerman, Foundations at 131-62 (cited in note 1) (advancing the idea of "intergenerational synthesis" and indicating that he will provide particular interpretations in these terms in the projected Volume III, Interpretations).

"For examples of interpretations of Ackerman's work as an attempt te develop a broad form of originalism, see Laura Kalman, Border Patrol: Reflections on the Turn to History in Legal Scholarship, 66 Fordham L Rev 87, 93-94, 97 (1997); Michael C. Dorf, Integrating Normative and Descriptive Constitutional Theory: The Case of Original Meaning, 85 Georgetown L J 1765, 1774-83 (1997); Fleming, 65 Fordham L Rev at 1337-38, 1344-55 (cited in note 47); Martin S. Flaherty, History "Lite" in Modern American Constitutionalism, 95 Colum L Rev 523, 579-90 (1995); Fleming, 11 Const Comm at 369-70 (cited in note 3); Suzanna Sherry, The Ghost of Liberalism Past, 105 Harv L Rev 918, 933-34 (1992); Michelman, 97 Yale $L J$ at 1521-23 (cited in note 38). 
meaning or original understanding, ${ }^{75}$ and to that extent to deny creativity in interpreting it.

As long as Ackerman conceives interpretation in terms of some form of broad originalism, he is likely, when he attempts to develop interpretations that attain intergenerational syntheses, to provide some of his own myths of rediscovery. The proof of this suggestion hes in the fact that some of Ackerman's acolytes, notably Lawrence Lessig, have been driven by their quests for forms of broad originalism to develop accounts of fidelity as translation, as opposed to accounts of constitutional transformation: Lessig's account of the New Deal deradicalizes Ackerman's account of the creativity of transformation in favor of a quest for fidehty in translation of original meaning, which amounts to a sophisticated myth of rediscovery. ${ }^{76}$ The best way to avoid the tondency to propagate myths of rediscovery is to eschew originalism, both narrow and broad, in favor of a theory of interpretation that conceives fidehty to the Constitution as intogrity with the moral reading of the Constitution. Such a theory can acknowledge change in interpretation without needing to dress it up in the garb of translations of original meaning or transformations of popular sovereignty.

\section{Conclusion: THE CONSTITUTION GOES TO YALE}

In concluding, I return to the puzzle that I posed in the introduction: How is it possible that Ackerman could beheve it necessary to develop his theory of constitutional amendment and transformation outside Article V in order to realize "the possibility of popular sovereignty" and "the possibility of intorpretation"? The difficulties with Ackerman's dualism-which underhe the problems with these two claims-are difficulties in his conceptions of democracy and intorpretation, respectively. The root difficulties in Ackerman's conceptions bear deep affinities to those in the ideas of his former Yale colleagne, Bickel (not to mention those in the work of his current Yale colleagne, $\operatorname{Amar}^{77}$ ).

${ }^{75}$ See Fleming, 65 Fordham L Rev at 1336-38 (cited in note 47) (criticizing both narrow originalist and broad originalist understandings of the idea of fidelity in constitutional interpretation).

${ }^{76}$ See, for example, Lawrence Lessig, Fidelity and Constraint, 65 Fordham L Rev 1365 (1997); Lawrence Lessig, Understanding Changed Readings: Fidelity and Theory, 47 Stan L Rev 395 (1995); Lawrence Lessig, Fidelity in Translation, 71 Tex L Rev 1165 (1993). Ackerman criticizes Lessig's "legalist" account of the New Deal-which addresses the question in terms of translation rather than transformation-for playing into the "reigning professional narrative," part of which is the "myth of rediscovery" (pp 290, $477 \mathrm{n} \mathrm{26).}$

7 Both Ackerman and Amar attempt either to dissolve or to resolve the "countermajoritarian difficulty" through offering theories of democracy grounded in popular sover- 
In recent years, some constitutional scholars have noted the emergence of a "Yale school" of constitutional theory, by which they refer to Ackerman's and Amar's theories of amending the Constitution outside Article V. ${ }^{78}$ But these theories are simply the latest symptom or manifestation of deeper difficulties in conceptions of democracy and interpretation that have plagued Yale constitutional theorists since Bickel. By the formulation "the Constitution goes to Yale," I mean to suggest that Yale seems to foster or generate constitutional theories that are haunted or hobbled by the root difficulties of Bickel's theory, which were reflected in his formulation of and response to the "countermajoritarian difficulty." The first difficulty was that Bickel held an impoverished conception of democracy as majoritarian representative democracy, within which not only judicial review but even fundamental rights were deviant and anomalous rather than integral. ${ }^{79}$ The second was that Bickel held an impoverished conception of intorpretation. He rejected the classical, interpretive justification of judicial review, and sought to develop a "noninterpretive" justification grounded in preserving fundamental values. ${ }^{80}$ Yet he proved incapable of articulating a post-realist conception of intorpretation that could withstand skeptical and democratic objections to every conceivable source of fundamental values. ${ }^{81}$ Thus, his quest for a source of fundamental valueswhich Ely aptly called the "odyssey of Alexander Bickel"-became a nightmarish free-fall. ${ }^{82}$

eignty whereby We the People may amend the Constitution outside Article V. In different ways, both Ackerman and Amar level the Constitution and along with it the idea of popular sovereignty. Ackerman's conception of popular sovereignty leads him to supplement Article V with sustained super-monism, whereby We the People must be free to amend the Constitution through sustained popular movements. Amar levels the Constitution further, by advancing a majoritarian conception of popular sovereignty that supplements Article $V$ by allowing amendment of the Constitution through majoritarian national referenda. See Amar, 94 Colum L Rev 457 (cited in note 6); Amar, 55 U Chi L Rev 1043 (cited in note 8).

${ }^{78}$ See; for example, Laurence H. Tribe, Taking Text and Structure Seriously: Reflections on Free-Form Method in Constitutional Interpretation, 108 Harv L Rev 1221, 1246 (1995).

${ }^{77}$ See Bickel, The Least Dangerous Branch at 16-18 (cited in note 7).

${ }^{30} \mathrm{Id}$ at 1-28.

${ }^{81}$ See Ely, Democracy and Distrust at $43-72$ (cited in note 29) (criticizing "noninterpretivist" theories of "discovering fundamental values," including Bickel's theory, on the ground that they are vulnerable to skeptical and democratic objections). For an analysis of Bickel's work in relation to the quest for a "post-realist Constitution," see Edward A. Purcell, Jr., Alexander M. Bickel and the Post-Realist Constitution, 11 Harv CR-CL L Rev 521 (1976).

2 Ely, Democracy and Distrust at 71-72 (cited in note 29). In referring to Bickel's odyssey as "mightmarish," I mean to echo Hart's notion of the "nightmare" of judges never finding, but always only making, law. See Hart, The Nightmare and the Noble Dream at 126 (cited in note 35 ). 
Ackerman began Discovering the Constitution-which launched the We the People project in 1984-by claiming that he would "rediscover the Constitution" and dissolve the "countermajoritarian difficulty" that haunted Bickel by reclaiming or reconstructing the classical, interpretive justification of judicial review. ${ }^{83}$ That certainly was a promising beginning. And one might well have believed that Ackerman had the tools to rescue constitutional theory from the difficulties in, and brought on by, Bickel's work. For one thing, Ackerman's understanding of democracy as dualist is richer than Bickel's. For anotler, Ackerman's understanding of interpretation as "constructive" is more sophisticated than Bickel's, and it is staunchly post-realist. ${ }^{84}$ All in all, Ackerman is far more sophisticated than Bickel in what the latter called "the method of reason familiar to the discourse of moral philosophy. ${ }^{\text {ng5 }}$

But Ackerman is hobbled by the quest for "the possibility of popular sovereignty," just as Bickel was haunted by the "countermajoritarian difficulty." Accordingly, Ackerman develops a theory of democracy that reduces or recasts our Constitution and constitutional democracy into the mold of popular sovereignty, just as Bickel rejected as deviant any feature of our constitutional scheme that did not conform to a theory of majoritarian representative democracy. (Amar is either the synthetic culmination or the reductio ad absurdum of the Yale school, for he fundamentally conceives popular sovereignty as majoritarian representative democracy.) And Ackerman pursues "the possibility of interpretation," whereas Bickel searched for a "noninterpretive" justification of judicial review. This leads Ackerman to develop a pluralist conception of the sources of higher lawmaking outside Article $V$, just as Bickel searched for a source of fundamental values outside the Constitution altogether.

As agaimst Ackerman's and Bickel's theories, we need a conception of constitutional democracy of the sort I sketched here te avoid the theoretical hankering te transform our "incorrigible," "irreducible" dualist Constitution into the molds of popular sovereignty and majoritarianism. And we need a conception of inter-

Ackerman, 93 Yale L J at 1013-16 (cited in note 19).

\& See Bruce A. Ackerman, Reconstructing American Law (Harvard 1984). For example, he exhorts us to "have the strength to question the realist banalities of contemporary legal thought" and to move "beyond realism" (pp 417-19).

${ }^{85}$ Alexander M. Bickel, The Supreme Court and the Idea of Progress 87 (Yale 1978). The statement in the text is borne out not only by Ackerman's work in constitutional theory but also by his work in political theory. See, for example, Bruce A. Ackerman, Social Justice in the Liberal State (Yale 1980). 
pretation like Dworkin's to reclaim the dualist justification of judicial review from Ackerman's reconstruction of it and to rescue the fundamental rights justification of judicial review from Bickel's "noninterpretive" defense of it. Such conceptions offer hope of preserving and realizing our exceptional, unconventional Constitution. 